\title{
THINKING HATTUSHA: ASTRONOMY AND LANDSCAPE IN THE HITTITE LANDS
}

\author{
A. CÉSAR GONZÁLEZ GARCÍA and JUAN ANTONIO BELMONTE, \\ Instituto de Astrofísica de Canarias \& Departamento de Astrofísica, \\ Universidad de La Laguna
}

\begin{abstract}
It is of note that no special direction of the compass seems to have been preferred either for the orientation of the temples or for that of the cult chamber themselves.
\end{abstract}

Jürgen Seeher

As a natural sequel to studies of temple orientation in the Mediterranean basin, and especially of the temples of ancient Egypt, ${ }^{1}$ the Hittite monuments of the Bronze Age offer an excellent laboratory to extend further the analysis of possible astronomical or topographical orientations, or both. This would be relevant not only for comparison with other neighbouring and contemporary cultures, but also to provide insights into such an important region of the Middle East as the Anatolian Peninsula.

Contemporaneous with the Egyptian New Kingdom, the inhabitants of the Hittite Empire and their masters, the Kings of the Land of Hatti, produced a most sophisticated society, heir to a long Anatolian cultural tradition lasting several millennia. ${ }^{2}$ However, to our knowledge, cultural astronomy studies in this area and particular period have been practically nil. ${ }^{3}$ Preliminary analysis of some Hittite monuments and of the written sources had shown certain clues to a possible interest in the sky, but the judgement of Jürgen Seeher, ${ }^{4}$ the director of the team currently excavating at Hattusha, the Hittite capital, was so categorically negative regarding the question that apparently there was no hope of obtaining a positive result.

However, it is the intention of this article to show that the analysis of a statistically significant sample of Hittite temples - and a handful of monumental gates - demonstrates that ancient Hittite monuments were not randomly orientated. On the contrary, there were well-defined patterns of orientation that could be interpreted within the context of Hittite culture and religion. The Hittite sample will be complemented with a preliminary set of data for Phrygian religious monuments. This will serve to analyse the transition of orientation customs from the Late Bronze Age to the Early Iron Age. This sample from ancient Phrygia will be compared with data in the excellent work of Susanne Bernt-Ersöz. ${ }^{5}$

The paper deals with different topics. In Section 1, we analyse the geographical, historical and anthropological context. Special care is devoted to analysing ancient Hittite religion within its Anatolian context, notably the solar cults and the festival calendar. Section 2 presents our data on the Hittite monuments and tries to offer clues to their interpretation. The Phrygian data are presented and analysed in Section 3, offering a basis for future research. Finally, Section 4 presents the conclusions, both definitive and preliminary, of our work. 


\section{STATE OF THE QUESTION: INTRODUCTION}

The Hittite Empire was a multi-lingual, multi-cultural political entity that controlled the life of Anatolia and the Levant for more than three centuries. From their homeland in the Land of Hatti (see Figure 1), the Hittite kings dominated a vast territory of varying frontiers which at its maximum extent in the late thirteenth century B.C. included, thanks to a network of vassal states, most of Anatolia and the north of Syria. The nucleus of the kingdom was formed by the Land of Hatti proper, the Upper and Lower Lands, and the neighbouring territories of Kizuwatna and Tarhuntassa. This area was populated not only by Hittites, speaking "Nesili", the language of Nesha, but also by Luwians and Palaians, speaking parentage languages of Indo-European lineage, Hurrians (notably in Kizuwatna) and, to an extent difficult to discern, ancient Hattians, the original inhabitants of the region. It has been argued that the latter group language, Hattic, was a dead language used only in religious rituals during most of Hittite history and that, at the end of the kingdom (c. 1200 B.C.), even Nesili was

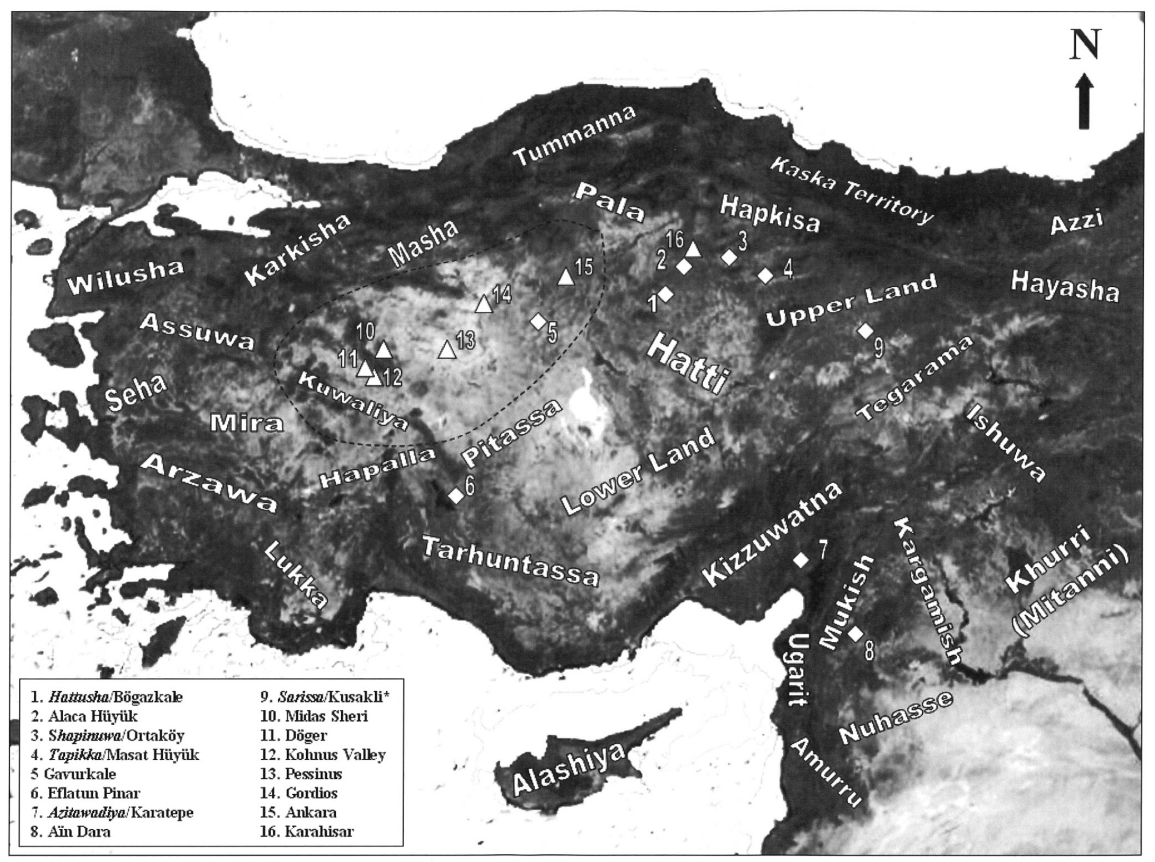

FIG. 1. Anatolia in the Late Bronze Age during the apogee of the Hittite Kingdom (13th and 14th centuries B.C.). From their homeland, the Land of Hatti, the Hittites dominated the vast majority of Anatolia and extended regions of northern Syria. The map shows the sites where data presented in this paper have been collected. Diamond signs stand for ancient Hittite sites (ancient name in italics) and triangles for later Iron Age Phrygian sites whose data are used for comparison. The dot-curve shows the area of central Phrygia $c$. 8th century B.C. 
used only for state politics and religious purposes, while Luwian was the language spoken by the vast majority of the population. ${ }^{6}$

As a consequence of this population mix, Hittite religion and social customs were a complicated blend of different traditions. The case of religion is especially significant since Hittite and Luwian creeds, with Assyrian influences, were imposed on an original substrate of more ancient Hattian beliefs. ${ }^{7}$ To further complicate the situation, certain aspects of Hurrian beliefs exercised a notable influence on Hittite religion after a dynasty possibly of Kizuwatnean origins seized power in Hattusa with Tudhaliya I (c. 1400 B.C.) and his successors. This dynasty would be the one of the creators of the empire. ${ }^{8}$ Hence, it comes as no surprise that the original sources spoke of the "Thousand Gods of Hatti", and that Hittite religion sensu strictu has been considered a syncretistic system favoured by the state. ${ }^{9}$

It is not the intention of this paper to produce a review on ancient Hittite religion but rather to concentrate instead on those aspects of the cult that could be of interest to our work. These will be the solar, and other astral, divinities, the sacred space temples, shrines and monumental gates - and its administrators, the calendar of festivals - i.e. Hittite sacred time - and, finally, the cult of the dead and related spaces and topography.

\subsection{Astral Cults in the Hittite Lands}

The important role played by solar deities among several ancient cultures is often accepted. However, when it is the Hittites that are under consideration, this characteristic is seldom emphasized. This could be due to the extreme difficulty in understanding sun cults and solar divinities in this particular case. ${ }^{10}$ In the ancient Hattic language, the sun, Eshtan, had a female character personified in a Sun-goddess of ancient Hattian origin with multiple faces, whose roots can be traced in Anatolia (see Figure 2). Frequently called Warushemu, "Mother of the Earth", she was known as the Sun-goddess of Arinna, Lady of the Land of Hatti, from the beginning of the empire onwards. She formed the supreme coupling of Hittite religion with the Storm-god of Hatti, although she is usually listed before the Storm-god in the dedicatory lists. ${ }^{11}$ The king was the supreme priest of her cult. Besides, the Sun-Goddess of the Earth, an avatar of the Sun-Goddess of Arinna, represented the sun's course during the hours of the night, while conveying the spirits of the dead to the underworld with the help of the so-called "twelve deities of the underworld". ${ }^{12}$

The problem arises when another solar deity is brought into consideration. This was the Sun God of Heaven, a clearly male aspect of the deity. He was called Ishtanu (to be compared with the Hattic female Eshtan) by the Hittites, while in parallel Luwian, Hurrian or Akkadian texts he is identified with Tiwad, Shimegi and Shamash, the corresponding male solar deities, respectively. Hittite kings refer to themselves as "My Sun", while a winged solar-disk was used to crown the eadicula for royal names in monumental inscriptions and royal seals (see Figure 2). In fact, the Hittite kings often mirrored the image of the Sun God of Heaven (see Figures, 3, 4 and 5). In contrast, 

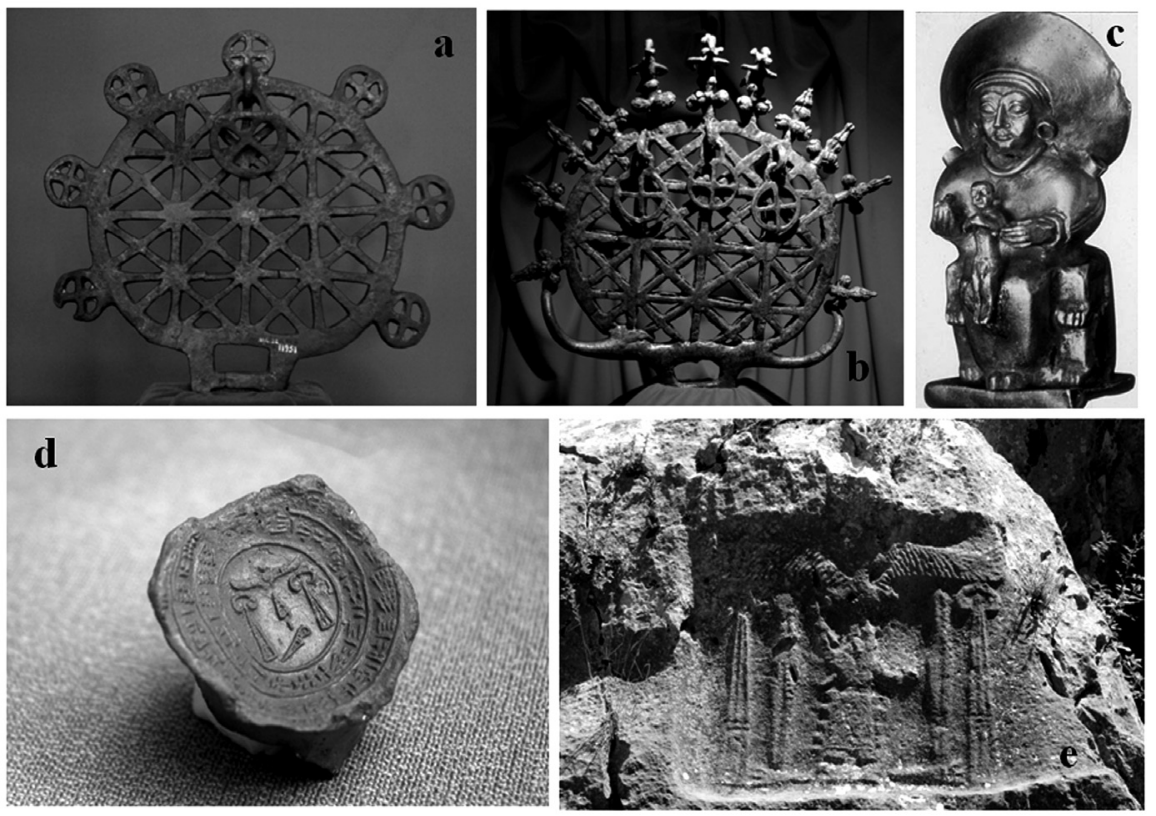

FIG. 2. Solar symbolism in Hittite art and writing: $(a)$ and $(b)$ proto-Hittite metal discs with possible astral symbolism from excavations in Alaca Hüyük, $c$. 18th century B.C.; $(c)$ a golden statuette of a sitting goddess, possibly the Sun-goddess of Arinna from Hattusha; $(d)$ the seal of Mursili II found in excavations at Hattusha; and (e) the Luwian hieroglyph aedicula of Tudhaliya IV in Chamber B at Yazilikaya. Notice the winged disc of the sun in the last two images. Photographs courtesy of Margarita Sanz de Lara $(a)$ to $(d)$ and César González García $(e)$, and the Anatolian Civilization Museum.

the Tawanana, the Hittite queen, identified herself with the Sun-goddess of Arinna. ${ }^{13}$

Was, then, the sun male or female within the Hittite civilization context? Several scholars have devoted time and resources in an attempt to solve this question without reaching a solution, or even a consensus. Some specialists have tried to solve it from a chronological point of view, arguing that the Sun God of Heaven is a later addition to the Hittite pantheon. However, it has been demonstrated that Hattushili I (c. 1650 B.C.) already rendered cult to him. ${ }^{14}$ The Sun God of Heaven was such an important deity that he was first in the list of witnesses of international treaties.

Apparently, Hittites themselves were happy to live with a double male and female personification of the sun divinity, and this apparent dichotomy was not the cause of dialectic problems. This can be perfectly traced in the original sources, such as the following paragraph:

Thus says tabarna Muwatalli, Great King, King of Hatti, son of Mursili, Great King, King of Hatti, the Hero: if some problem burdens a man's conscience, 


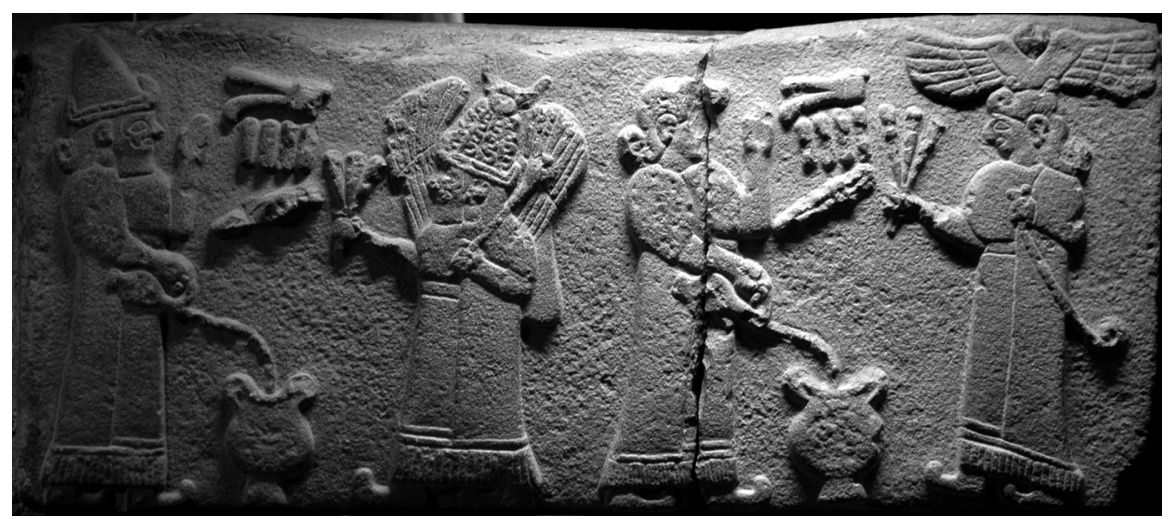

FIG. 3. King PUGNUS.meli of Melid during the Iron Age (c. 740 B.C.) offering libations to the Moon god of Harran, curator of pregnancy and perhaps related to the calendar, and the Sun God of Heaven, the protector of the Hittite dynasty. These deities received different names in Hattic (where the sun is feminine), Hittite, Luwian and Hurrian, the four most common languages of the Hittite lands, and it is frequently difficult to ascertain whose divinity it is that is mentioned in a certain text. Photograph courtesy of Margarita Sanz de Lara and the Anatolian Civilization Museum.

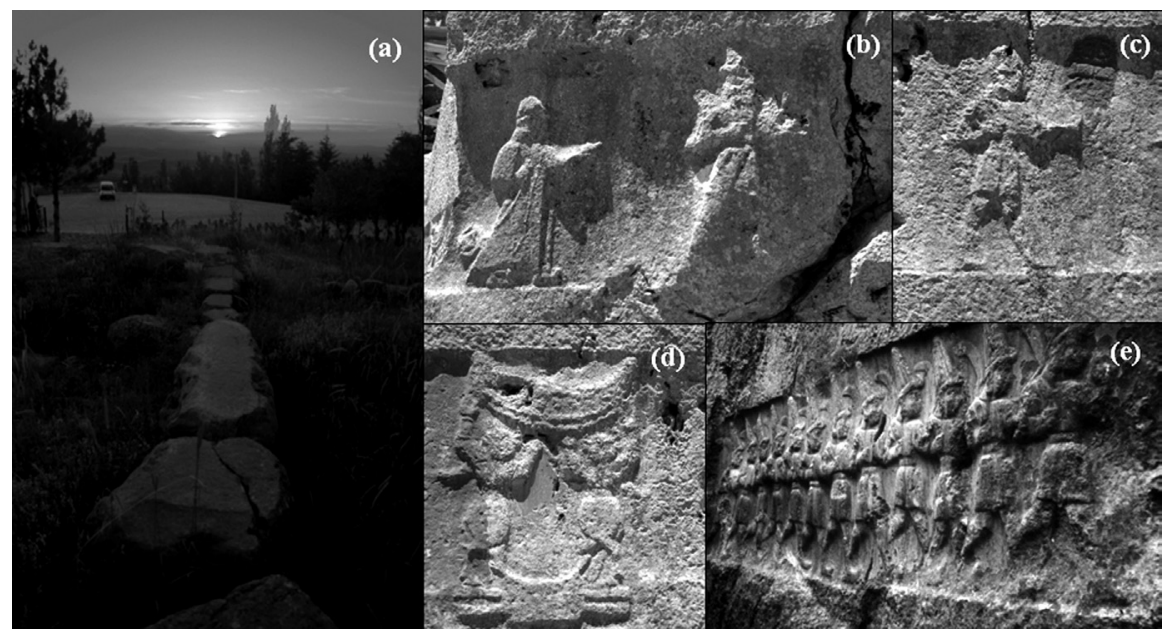

FIG. 4. Images of Yazilikaya, the important religious enclosure to the northeast of Hattusha, outside the walls. Summer solstice sunset alignment of the monumental gate of the sacred precinct $(a)$. Sections of the procession of male deities with an astral character in Hall A showing: the winged Moon-God and the Sun God of Heaven $(b)$, winged god(dess) Pirengir $(c)$ and the bulls Serri and Hurri holding up the sky while standing on the sign of the Earth $(d)$. Finally, the twelve gods of the underworld in the western wall of Hall B (the number of these divinities might be related to the twelve months of the year) $(e)$. See the text for further discussion. Photographs by Juan Antonio Belmonte, $(a)$, and Margarita Sanz de Lara, $(b)$ to $(e)$. 


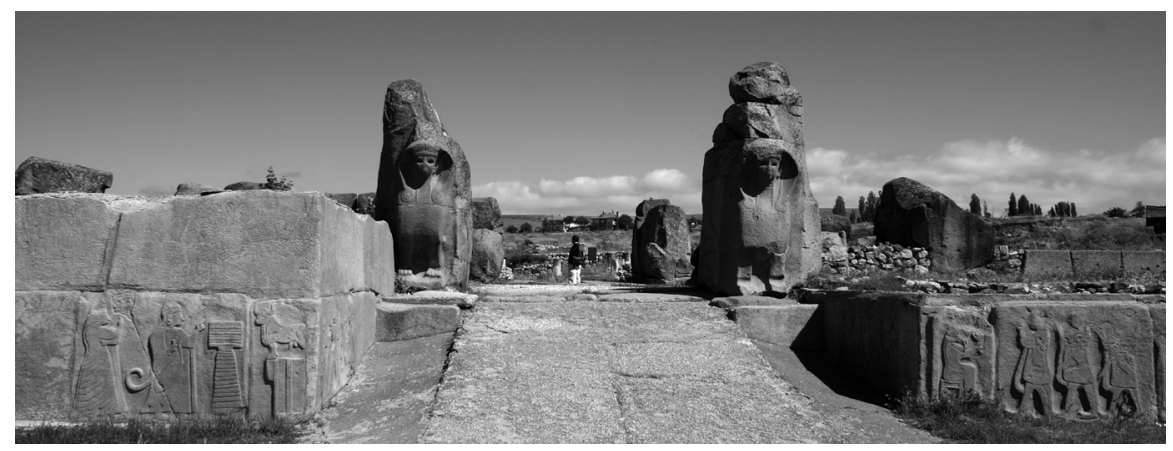

FIG. 5. The monumental gate of the sphinxes in Alaca Hüyük, certainly a most important cultic place of the Land of Hatti. The sacred character of the gate is shown by the images of divine adoration (right) to the Sun-goddess of Arinna by a procession of servants, and (left) to a bull, standing for the Storm-god of Hatti, by the king himself. The ruins have been identified with the sacred cities of either Arinna or Zippalanda. Photograph by César González García. See the text for further details.

he makes a plea to the gods. He places on the roof, facing the sun, two covered wickerwork tables: he places one table for the Sun-Goddess of Arinna, and for the male gods one table. On them there are: thirty-five thick breads of a handful of moist flour, a thin bowl of honey mixed with fine oil, a full pot of flat-bread, a full bowl of groats, thirty pitchers of wine. And when he prepares these, the king goes up to the roof and he bows before the Sun God of Heaven. ${ }^{15}$

The text clearly illustrates that King Muwatalli II (c. 1295-1272 B.C.) simultaneously established an offering table to the Sun-goddess of Arinna and addressed the Sun God of Heaven within the same ritual context. Indeed, the paragraph also indicates the importance of solar orientations of offering tables and sunward-bowing persons and perhaps of the sacred buildings where these actions took place. This will be most relevant in the incoming discussion. Additionally, given the importance of the sun and solar cults, it is not strange that the Hittites paid attention to uneven solar phenomena. In this respect, a prayer of Mursili II (c. 1321-1295 B.C.) reports a solar omen that occurred while he was on campaign in the land of Azzi in his ninth or tenth regnal year. Often identified as a solar eclipse, it has allowed the dating of Mursili's tenth year to 1311 B.C. and the fixing of the chronology of the period. ${ }^{16}$

The Moon, Kashku in Hattic, was not prominent in Hattian beliefs and it is not even clear whether it was personified or not. However, in the Hittite period, the Moon-god gained special prominence, especially under Hurrian and Luwian influence. ${ }^{17}$ The lunar divinity, Arma in Luwian, and Kushuh in Hurrian, was represented winged and with a tiara topped by a crescent (see Figures 3 and 4). He was considered as the protector of the months of pregnancy and as the patron of the month festival possibly celebrated at full-moon. He was probably related to time-keeping. That the moon was indeed observed is indicated by the fact that relevant manuals dealing with 
lunar omens confirm that a lunar eclipse could have announced such a disastrous event as the death of the king. ${ }^{18}$ Consequently, we will have to include the moon as one of our possible 'targets' for the orientation of Hittite monuments.

The goddess Shausga also enjoyed a double nature that equated her to the Assyrian Ishtar and the Sumerian Inanna. The Mesopotamian divinity was a personification of the planet Venus, as a warrior god(dess) as Morning Star, and as the goddess of love and fertility in the role of the Evening Star. Shausga is represented in this double (male-female) nature in the reliefs of the open-air sanctuary of Yazilikaya, to the north-east of Hattusha (see Figure 6). It would be logical to assume this double astral character for the Hittite divinity, provided she reached the Hittite pantheon under Hurrian and Assyrian influence. ${ }^{19}$

However, there is an enigmatic divinity known as Pirinkir or Pirengir who is mentioned in certain text as an ISHTAR.MUL (Ishtar-like star or "heavenly body" of Ishtar) divinity and who is perhaps represented within the male divinities procession in Yazilikaya (see Figure 4). It is worth noting that, with the exception of the

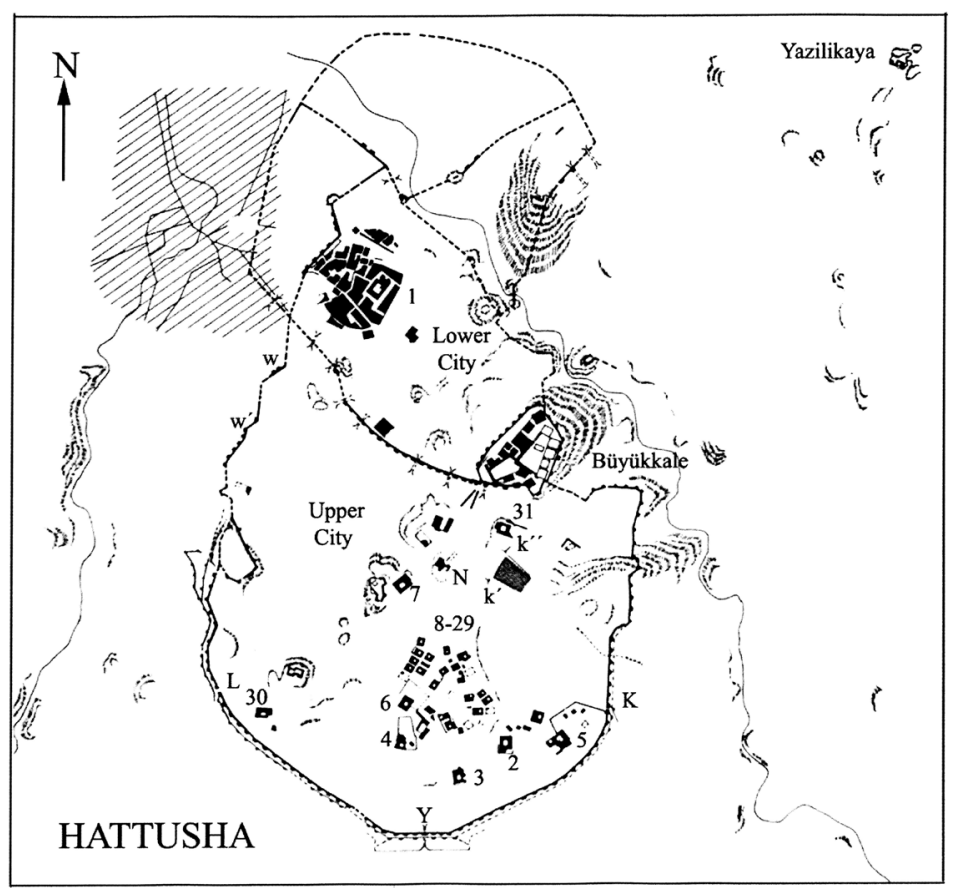

FIG. 6. Plan of Hattusha, the Hittite capital, showing the location of the monuments described and discussed in the text. Temples are listed from 1 to 30. K, Y, and L stand for King, Sphinx (Yerkapi) and Lion gates, respectively. $\mathrm{W}$ and $\mathrm{W}^{\prime}$ stand for the poorly-preserved western monumental gates. $\mathrm{N}$ stands for Nisantas monument and inscription, while $\mathrm{k}^{\prime}$ and $\mathrm{k}^{\prime \prime}$ stand for Chambers 1 and 2, in the Südburg area. Notice the sector of Yazilikaya far to the northeast of the city walls. 
Sun-goddess of Arinna, all divinities standing for heavenly bodies were apparently represented with wings in Hittite art. Consequently, some authors have proposed that Pirinkir has to be identified with the Morning Star. ${ }^{20}$ Hence, we are again facing a dichotomy: who is the personification of the planet Venus, Pirinkir or Shausga? In the present state of knowledge, it is difficult to favour one choice over the other although the present authors tend to favour the Shausga hypothesis. Who or what would then be the celestial equivalent of Pirinkir? Most probably another planet, perhaps Mercury, which also had a double nature as morning and evening star that mimicked the behaviour of Venus, or even a bright star (see below, Section 2.2), but these suggestions should be treated with caution until new textual or epigraphic evidence is adduced to support or contradict them.

There is hardly any other evidence of stellar cults in the Land of Hatti although there is a brief mention of the Pleiades in the context of the rituals celebrated during the purulli festival (see below, Section 1.3) which might suggest an interest in this important time-keeping asterism. ${ }^{21}$

We would not like to end this excursus on astral divinities without talking about an important Hittite monument known as Eflatun Pinar (see Figure 7). This highrelief façade was integrated within an impressive spring sanctuary created in the late phases of the empire either by the King of Hatti or by a local petty-king. It arguably represents a Hittite cosmogram where the central figures are the supreme gods of the pantheon, the Sun-goddess of Arinna and the Storm-god of Hatti, supported by mountain gods at the lowest level and framed by bull-head genii sustaining the sky above. A pair of these bulls have been identified as the celestial bulls Serri and Hurri, drivers of the Storm-god chariot, in a relief of much reduced scale in the walls of Yazilikaya (see Figure 4). ${ }^{22}$

In summary, astral, notably solar, divinities were certainly important in the Hittite pantheon. Considering the precedents for other civilizations within a similar religious context, it would be expected that solar, or astral, orientations were common amongst the sacred buildings of the Hittites.

\subsection{Sacred Spaces: Temples, Monumental Gates and Sacred Mountains}

There is an impressive collection of ancient temples dating from the Bronze Age and especially from the Hittite period in Anatolia. No standing building has survived from that epoch because the walls of the temples and shrines were built with a combination of timber and mud-bricks, in a most sophisticated way but one that has not withstood the elements in a region where rain and snow are frequent. Fortunately, the stone fundaments of a large number of buildings have survived, sometimes even to a megalithic scale, in a fairly good state of preservation. ${ }^{23}$ They were normally planned around a central courtyard onto which the adyton of the deity (or deities in certain cases) and several other chambers opened.

Some original temple foundation texts have been preserved in cuneiform tablets. ${ }^{24}$ Although these include numerous rituals for the gods in order to obtain a propitious 


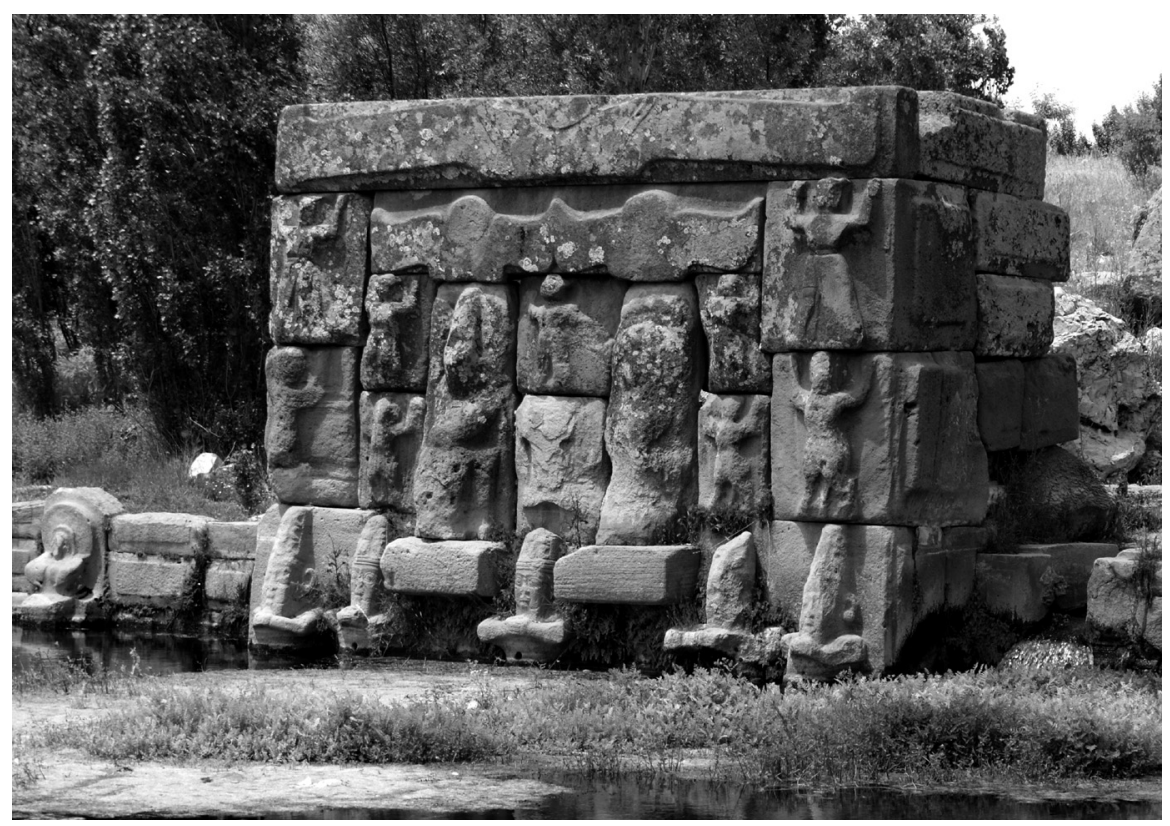

FIG. 7. A Hittite 'cosmogram', as beautifully represented in the spring-shrine of Eflatun Pinar. The Storm-god of Hatti and the Sun-goddess of Arinna, supreme deities of the Hittite pantheon, are framed by symbols of the heavens (winged sun-disks) and the earth (mountain-gods), and genii and bull-men support the sky. This interesting monument was built in the outskirts of the Land of Hatti, c. 1200 B.C., by an unknown member of the imperial, or even a local, dynasty. Photograph by César González García. See the text for further information.

venture, and the description of certain foundation deposits of bronze plaques, there is nothing in the Hittite lands similar to the elaborate ancient Egyptian ceremony of the stretching of the cord where astronomical orientation played a most significant role. ${ }^{25}$ On the contrary, it has been the general scholarly impression that there appears to have been no particular importance paid to the direction in which temples face. ${ }^{26}$ Actually, the holy of holies in most of the temples was off-centre, deliberately so designed to ensure there was no direct view into it from the entry portal. ${ }^{27}$ This fact seemed to support the general idea that orientation was not important in the design of sacred buildings.

Most Hittite cities, and especially those with a marked sacred character like Hattusha or Alaca Hüyük, ${ }^{28}$ had monumental gates that certainly served other than merely defensive purposes. Some were profusely decorated with ritual scenes (see for example Figure 5) and others, like the monumental gates of Hattusha's Upper City, followed a symmetrical layout that has been interpreted within a ceremonial and ritualistic context (see Figure 6). ${ }^{29}$ This tradition extended well after the end of the empire in Neo-Hittite cities such as Kargamish or Azatiwataya (modern Karatepe, 
see Figure 1)..$^{30}$

Hittite religious spaces were completed with sacralized springs and mountains. Middle Hittite texts describing sanctuaries beside a spring dedicated to the Storm God of Hatti and the Sun-goddess of Arinna have been found in the epigraphic material, ${ }^{31}$ and shrines built to a monumental scale, like Eflatun Pinar, have been identified in the archaeological record close to springs and water tables.

Mountains were most important in Hittite sacred topography. They were often identified as the seats of important local gods, such as the Storm-gods of Arinna and Zippalanda (see Figure 8). Frequently, they were even personalized as divinities invoked and involved in ceremonies and rituals such as Mountain Tudhaliya, an unidentified peak in the surrounding of Hattusha. ${ }^{32}$ This peak was so important as to be carried as a personal name by three Hittite kings, including the founder of the imperial dynasty Tudhaliya I, and the king who brought Hattusha to its maximum monumental splendour, Tudhaliya IV (c. 1227-1209 B.C.), whose Luwian hieroglyph name includes a representation of the mountain-god (see Figure 2). Provided these mountains can be clearly identified, they may constitute relevant landmarks of the local sacred landscape and could be transformed into important reference points of the local horizon of temples, shrines and monumental gates since, as stated by ancient

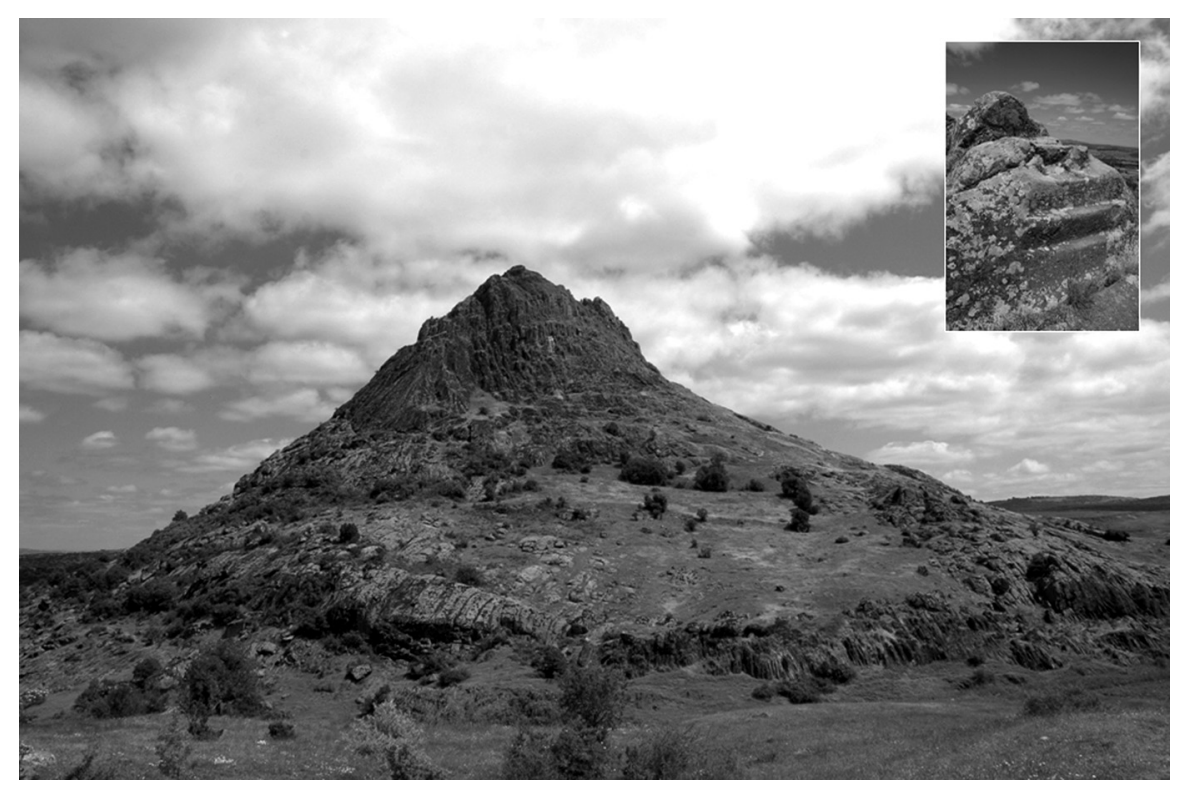

FIG. 8. The impressive peak of Karahisar, standing above the Anatolian plain a few kilometres to the north of Alaca Hüyük. It has been identified either with the sacred mountain of Hulla in Arinna, or with that of Daha(ya) in Zippalanda, seats of the local Weather God. The remains of an elaborated Phrygian step-monument (top right) have been found in its summit, perhaps a recycled structure of the earlier Hittite period. Photographs by Juan Antonio Belmonte and César González García (top right). 
sources, mountains were used as temporary first stopping places for certain gods before they entered their temples at required moments of sacred time. ${ }^{33}$

\subsection{Sacred Time: The Feasts and Festivals of the Hittites}

The ancient Middle East is notable for a huge variety of cultic calendars with dozens of local variants that can exasperate the most dedicated scholar. ${ }^{34}$ This is indeed true for Hittite Anatolia where the fragmentary, and on some occasions contradictory, nature of the texts has prevented the establishment of a precise calendar for the Hittites, not even in the phase of the empire. Several sources offer diverse information that should be arranged in a more or less logical pattern. This is not an easy task.

For ancient Hittites, the celebration of special festivals to specific deities at their proper time was essential for maintaining the order of the universe. ${ }^{35}$ Each temple had a series of priests of different categories and various duties at its service. Some of them had special duties and were responsible for the celebration of festivals in due-time. In this line of argument, the SANGA-priest of the Sun-goddess of the Earth slept "under the stars" at the temple courtyard regularly and it is possible that one of his duties on those nights was astronomical observing for the appropriate timing of festivals. ${ }^{36}$

Lists of festivals of the old Hittite period and of the empire have been found, both in Hattusha and in other minor sacred villages of the Land of Hatti ${ }^{37}$ Indeed, as in many other cultures, both ancient and modern, sacred time was governed by a yearly cycle (although larger periods were also possible, see below) certainly connected to agricultural activities. In this sense, in central Anatolia, the crucial times of the agricultural year were fall, between September and November, and spring, between mid-March and mid-June, the times respectively of the reaping and the sowing. These were the moments of two of the most important Hittite feasts, the AN.TAH.SUM and the nuntarriyashas festivals. ${ }^{38}$

The AN.TAH.SUM festival, named after a flower involved in the rituals, often identified with a crocus or fennel, was a major festival with a duration of some 38 days (perhaps longer or shorter on occasion), a period in which the king and the Tawanana, together with other high ranking priests and priestesses, travelled around Hattusha and between this major city and other minor cult centres such as Arinna or Zippalanda. ${ }^{39}$ The precise timing of the festival within the year is unknown. It was established in its final form by King Hattushili III (c. 1267-1237 B.C.), after its presumed inauguration by King Suppiluliuma I (c. 1344-1322 B.C.) and a previous religious reform by Hattushili's father Mursili II (c. 1321-1295 B.C.). ${ }^{40}$ The festival was dedicated to the supreme gods of the land, the Sun-goddess of Arinna and the Storm-god of Hatti, and had a certain number of peculiarities. The most important for our interests are the activities celebrated on the 11th day of the feast when the "old year" was carried symbolically to the hešta-house (a sacred precinct connected with the ancestor cult) in Hattusha. ${ }^{41}$

It is likely that the Hittites counted their time in lunar months (the existence of the 
"festival of the month" is a trace of this) but we do not know the precise organization of this calendar or how they handled the rule (if any) to accommodate the lunar year with the cycle of the seasons, which was of course governed by the tropical (solar) year. Eleven days is the difference between the duration of a purely lunar year of 354 days and an average solar year of 365 days, so the special occasion of the AN.TAH.SUM festival 11th day could have a meaning within the context of an appropriate working lunisolar cycle. We will come back to this important point at the end of this section.

The other great festival, the nuntarriyashas, had several parallels with the "crocus" one. Translated as the festival of "haste", it lasted at least 40 days and was celebrated "when the king returns from the battle-field". ${ }^{42}$ There is certain evidence that, at least during the late imperial period, another important festival, the KI.LAM, was celebrated within the main festivals, although during the Old Hittite period this was an independent and most important festival celebrated in the honour of the tutelary divinities of the Land of Hatti. ${ }^{43}$ Unfortunately, its exact yearly timing is once more unknown.

One of the most historically important festivals of the Hittites was the purulli, originally celebrated in the sacred city of Nerik, and possibly in the autumn or early winter; it was moved to Hattusha, and celebrated close to, or even within, the AN.TAH.SUM festival "when the land prospers and thrives". ${ }^{44}$ It has been argued that the purulli was the original Hattic New Year feast celebrated in winter and that it was transferred to the spring after Mursili II's reforms, when the new year was moved from one season to another. ${ }^{45}$ However, the matter is far from clear.

To further complicate the situation, an oracle text informs us that "this year His Majesty proposes to winter in Hattusha. He will celebrate the customary festivals, the festival of the year, the thunder festival in Hattusha ...". ${ }^{46}$ This "festival of the year", or EZEN witassiya, was celebrated in winter and apparently was the moment normally selected for the enthronement of the king. ${ }^{47}$ It is also difficult to establish if this was the same as or different to the "winter festival" celebrated for the Sungoddess of Arinna in Hattusha. ${ }^{48}$ Was this, or both of them, connected to the winter solstice? To clarify this is indeed a crucial question when we are trying to interpret the results of our archaeoastronomical analysis correctly. In this respect, the sources also speak of a hahratar feast, the festival of the harvest, ${ }^{49}$ a feast that, considering the annual cycle in central Anatolia, ought to be celebrated in summer, possibly in relation to the summer solstice or perhaps later.

A last point to be discussed is the actual nature of the Hittite festival calendar; there is evidence of a cycle of thirteen regular festivals in the cult of the divine couple formed by Teshub and Hebat of Halab of Hattusha. Teshub and Hebat were the Hurrian divinities of the city of Halap, modern Aleppo in northern Syria; they were fully assimilated by the Hittites and identified with their supreme deities, the Storm-god of Hatti and the Sun-goddess of Arinna, respectively, a fact that is fairly evident in the reliefs of Hall A in Yazilikaya. These festivals were celebrated in Hattusha in a 
monthly cycle, with a 13 th festival only when an additional 13th intercalary lunar month was needed to accommodate the lunar and seasonal cycles. ${ }^{50}$

The question, then, is how the Hittites adjusted the cycles of the sun and the moon. There is scattered evidence that certain festivals, major and minor ones, were not celebrated on a regular yearly basis but over longer periods of time. Local festivals celebrated every three years have been suggested. There is also scarce evidence that some large festivals (or parts of them, such as the ceremonies of the 11th day of the AN.TAH.SUM festival) may have been celebrated on a six-yearly basis. Finally, there are proofs that the festival of the god Telepinu in the city of Hanhana was celebrated every nine years. ${ }^{51}$ Three years is the minimum necessary for operating a workable simple lunisolar cycle (if it is calibrated through independent solar or stellar observations) and six and nine are multiples of this period. Were the ceremonies of the AN.TAH.SUM festival 11th day connected to the coupling of the monthly and yearly cycles? This is a possibility that we should take into account, and which could be relevant for the later archaeoastronomical analysis of the data.

\subsection{Topography of the Dead: "Hegur" Peaks and "Stone" Houses}

An astronomical or topographical orientation of buildings of a funerary character is to be found in many cultures. ${ }^{52}$ Monumental buildings, from megalithic tombs to Muslim mausoleums, had patterns of orientation that can be interpreted within the relevant cultural, religious and sociological context. Unfortunately, the Land of Hatti had no funerary architecture on this scale. Indeed, no structure has yet been discovered that can with certainty be identified as a Hittite royal tomb. ${ }^{53}$ There are burials where the remains of the deceased were often placed in large jars, now called by the Greek term pithoi, in a contracted position with their heads facing towards the south-east. However, the bodies of kings and queens were, it seems, invariably consigned to the pyre. ${ }^{54}$ Apparently, the sovereign's soul had previously descended into the body of a slaughtered plough-ox that was also burnt afterwards, while the king's expectation was that of ascending to dwell with the gods of heaven, notably the Sun God. ${ }^{55}$

The absence of Hittite burial monuments is somewhat of a problem for an archaeoastronomer. However, there are some interesting structures that have been assigned a funereal character. It has been shown that several Kings of Hatti had a (divine) "stone-house", a sort of tomb where their ashes were deposited alongside what the sources called a hegur (eternal) peak, a sort of commemorative structure normally associated with a rocky outcrop or peak. ${ }^{56}$

It is highly probable that the monument known as Nisantas (or Nisantepe) in the Upper City of Hattusha was the hegur-peak of Tudhaliya IV erected by his son Shupiluliuma II (c. 1207 B.C.), the last of the Hittite Empire kings reported in the sources. It has been also suggested that Hall B of Yazilikaya was the location of Tudhaliya's "Stone-house" (see Figure 9), while the whole sanctuary may have acted as a sort of king's mausoleum. ${ }^{57}$ The impressive site of Gavurkalesi (see Figure 9), to the south of Ankara, with a megalithic vaulted structure and large-scale reliefs located on a rocky 
outcrop dominating a fertile valley, has also been suggested as the possible location of a hegur-peak plus stone-house combination of an unidentified king, ${ }^{58}$ while other hekur sanctuaries, for example for King Muwatalli II, have been identified in the epigraphic material but not yet in the archaeological record..$^{59}$

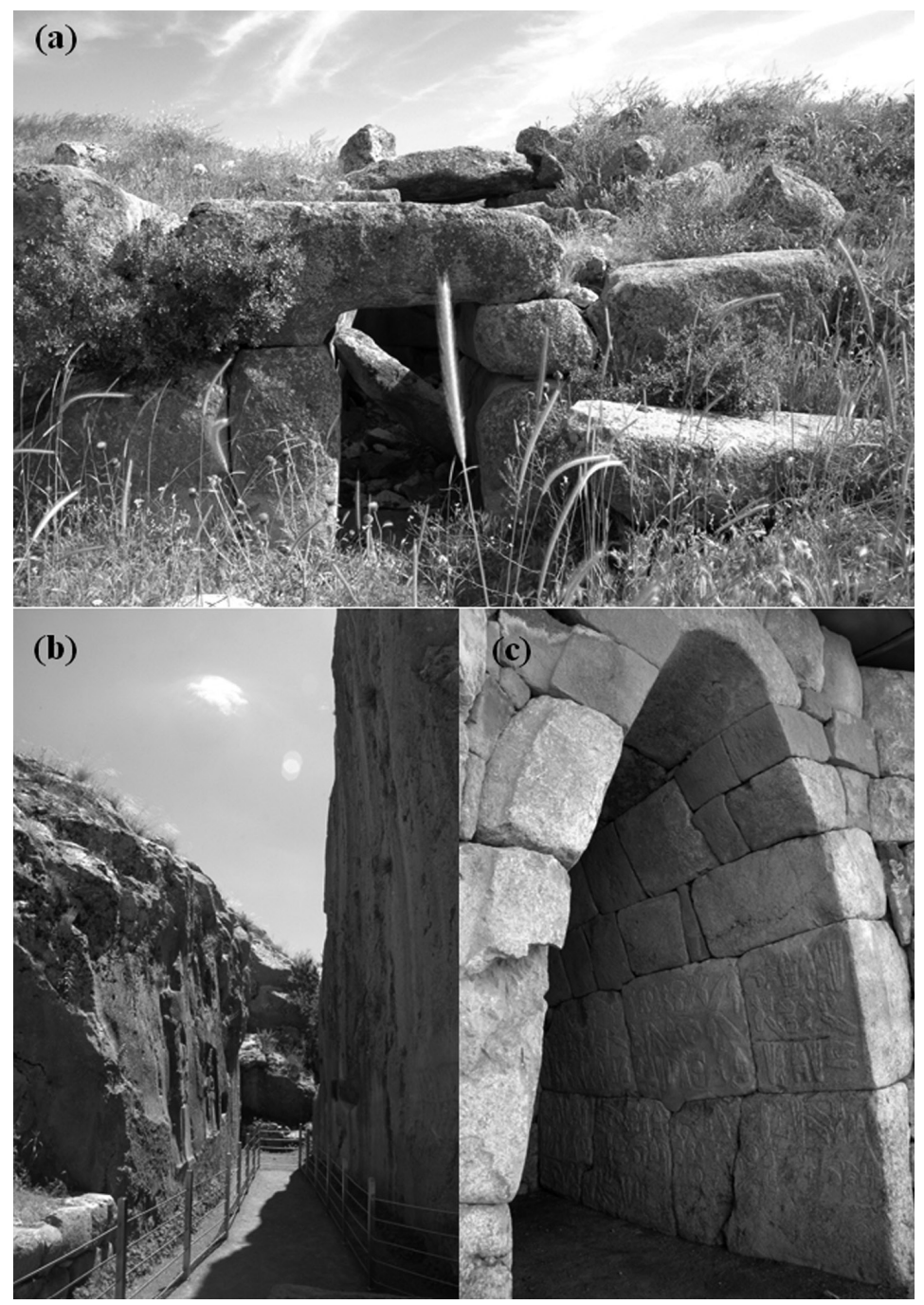

FIG. 9. Hittite monuments of a suggested funereal character: the unidentified cyclopean chamber on the summit of Gavurkalesi Hill (a), Tudhaliya IV's Hall B in Yazilikaya (b), and Suppiluliuma II's Chamber $2\left(\mathrm{k}^{\prime \prime}\right)$ in the Upper City of Hattusha $(c)$. All three structures are aligned in a close to the meridian axis, and the two monuments (and the decoration in Hall B) are facing north, suggesting a common purpose for such different structures. Photographs courtesy of Margarita Sanz de Lara. 
Finally, there are a couple of vaulted structures in Hattusha, named Chambers 1 and 2 , that might be included - especially the latter one - in the category of funereal monuments. These chambers are located in the so-called Südburg of Hattusha Upper City and are covered by the oldest vaults of stone masonry known in the Middle East. They were possibly built by Suppiluliuma II. This is certainly the case for Chamber 2, which was profusely decorated with a long inscription in Luwian hieroglyphs, still not fully deciphered, a representation of the king as a hero warrior, and a large high-relief of the Sun God of Heaven in the back-stone of the chamber (see Figure 9). This fact has suggested that the structure could be identified as a symbolic entrance to the Underworld. ${ }^{60}$

As to Yazilikaya, there are a few specialists who identify the site not simply as the mausoleum of Tudhaliya IV but as the actual location of the hesta-house, the mortuary shrine related to the AN.TAH.SUM festival and the site where the spirits of the dead Kings of Hatti dwelt. Its location far from the city nucleus would explain that the hesta-house had survived the unrest and destruction of much of Hattusa during the reign of Tudhaliya III (c. 1360-1344 B.C.), when most of the capital was destroyed by fire. ${ }^{61}$ However, the general opinion is that the hesta-house was located in Büyükkale, the acropolis of Hattusha. ${ }^{62}$

A "House of the Grandfathers" also related to the royal ancestor cult has been identified in the text that confirms the presence of such places in Hattusha and other cities that were royal residences at different stages of Hittite history. It would be helpful if these structures could be identified in the archaeological record, considering the parallels between those particular establishments and the "Sanctuary of the Stars" in Ebla and the "House of the Divine Stars" in Ugarit, sites related to the royal ancestor cult at these important Syrian ancient cities. ${ }^{63}$

In sum, the information that our analysis might provide concerning the Hittite topography of the dead is limited. However, as we shall see in Section 2, there are still reference points that may shed light on some controversial issues.

\section{DISCUSSION: ASTRONOMY AND LANDSCAPE}

Table 1 shows the data obtained in the early summer of 2009, in several Hittite sites of central Anatolia (see Figure 1). The campaign was programmed so that direct observations could be performed at some special locations at the moment of sunrise and sunset at the summer solstice. The table presents the standard data (site identification and coordinates), together with the archaeoastronomical data (azimuth or angular height (measured) and the corresponding declination (computed)), and comments on the measurements.

It is worth noting that, on most occasions, the temple-owner divinity or builder is ignored and most of the buildings are identified by prosaic ciphers or alphabetically. In a very few cases, this important information is known or suspected, as with Temple 1 in Hattusha (see Figure 10), built probably under the reigns of Hattushili III and his son Tudhaliya IV for the divine couple formed by the Sun-goddess of Arinna and the 
TABLE 1. Orientation of Hittite monuments (temples and monumental gates) as obtained in our mission in Anatolia in June 2009. The table shows for each monument the location, the identification of the temple or gate (either the most common name or owner deity), the latitude and longitude ( $\mathrm{L}$ and 1), the azimuth (a) from inside looking out, the angular height of the horizon (h) in that direction, and the corresponding declination $(\delta)$. The last column contains additional comments or data for alternative orientations. The sign $\rightarrow$ should be understood as "diverted towards". Data for Sarissa have been obtained from maps in literature. ${ }^{66}$

\begin{tabular}{|c|c|c|c|c|c|c|c|}
\hline Place & Monument & $\mathrm{L}$ & 1 & $\mathrm{a}$ & $\mathrm{h}$ & $\delta$ & Comments \\
\hline \multirow[t]{2}{*}{ Shapinuwa } & Temple D & $40^{\circ} 15^{\prime}$ & $35^{\circ} 14^{\prime}$ & $258 \frac{3}{4} \circ$ & $2^{\circ}$ & $-7 \frac{1}{2}^{\circ}$ & \\
\hline & Temple C & & & 247 & 2 & -16 & \\
\hline \multirow{5}{*}{$\begin{array}{l}\text { Alaca } \\
\text { Hüyük }\end{array}$} & Temple Complex Gate & 4014 & 3442 & $168 \frac{3}{4}$ & $2 \frac{1}{2}$ & $-46 \frac{1}{4}$ & \\
\hline & Porticus & & & $271 \frac{1}{4}$ & 2 & 2 & \\
\hline & Temple in Adyton East & & & $190 \frac{1}{2}$ & $0 \frac{1}{2}$ & $-48 \frac{1}{2}$ & \\
\hline & Temple in Adyton West & & & $190 \frac{1}{2}$ & $0 \frac{1}{2}$ & $-48 \frac{1}{2}$ & \\
\hline & Temple 6 & & & 91 & 2 & $0 \frac{1}{4}$ & \\
\hline Tappika & Stone Gate & 4009 & 3546 & 80 & 0 & $7 \frac{1}{4}$ & \\
\hline \multirow[t]{37}{*}{ Hattusha } & Temple 1 & 4000 & 3137 & 218 & 12 & $-27 \frac{1}{4}$ & Main Axis Gate Exterior \\
\hline & & & & 218 & 7 & $-31 \frac{1}{2}$ & Main Axis Deep Interior \\
\hline & & & & 128 & $9 \frac{1}{2}$ & $-21 \frac{1}{2}$ & $\perp \mathrm{E}$ \\
\hline & & & & 308 & 0 & $27 \frac{3}{4}$ & $\perp \mathrm{W}$ \\
\hline & & & & $126 \frac{3}{4}$ & 6 & $-23 \frac{1}{4}$ & Büyükkale North Base \\
\hline & & & & $131 \frac{1}{4}$ & $10 \frac{1}{2}$ & -23 & Büyükkale North Rim \\
\hline & & & & $122 \frac{3}{4}$ & $11 \frac{1}{2}$ & $-16 \frac{1}{4}$ & Main Gate \\
\hline & Grotto & & & $353 \frac{3}{4}$ & 0 & 49 & $\mathrm{i} \sim 20^{\circ} \quad 69 \frac{1}{2}$ \\
\hline & Temple 2 & & & $93 \frac{1}{2}$ & 2 & $-1 \frac{1}{2}$ & \\
\hline & Temple 3 & & & 90 & $1 \frac{1}{2}$ & $0 \frac{3}{4}$ & $0^{\circ} \mathrm{N}$ \\
\hline & Temple 4 & & & $109 \frac{1}{4}$ & 5 & $-11 \frac{1}{2}$ & Gate may open S \\
\hline & Temple 5 & & & 333 & 0 & $42 \frac{1}{2}$ & Ramp \\
\hline & & & & 58 & 3 & $25 \frac{1}{2}$ & East gate $(\rightarrow$ King Gate) \\
\hline & & & & $232 \frac{3}{4}$ & 7 & -23 & Towards Sphinx Gate \\
\hline & & & & $55 \frac{1}{2}$ & 3 & $27 \frac{1}{2}$ & Structure A \\
\hline & & & & 71 & $2 \frac{1}{2}$ & 16 & Structure B \\
\hline & Temple 6 & & & 127 & 6 & $-23 \frac{1}{4}$ & Gate may open $\mathrm{N}$ \\
\hline & Temple 7 & & & 53 & $2 \frac{1}{2}$ & 29 & $6^{\circ} \mathrm{SE} \rightarrow-33^{\circ}$ \\
\hline & Temple 8 & & & 269 & 0 & -1 & \\
\hline & Temple 9 & & & $304 \frac{1}{4}$ & 0 & $25 \frac{1}{2}$ & $5 \frac{10}{2} \mathrm{SW} \rightarrow-35^{\circ}$ \\
\hline & Temple 10 & & & $127 \frac{1}{2}$ & $6 \frac{1}{2}$ & -23 & \\
\hline & Temple 11 & & & $126^{\frac{1}{2}}$ & $5 \frac{1}{2}$ & $-23 \frac{1}{2}$ & \\
\hline & Temple 12 & & & 126 & $6 \frac{1}{2}$ & -22 & \\
\hline & Temple 15 & & & $122 \frac{3}{4}$ & $6 \frac{1}{2}$ & $-19 \frac{3}{4}$ & \\
\hline & Temple 17 & & & $266 \frac{1}{2}$ & 0 & -3 & \\
\hline & Temple 18 & & & 265 & 0 & $-4 \frac{1}{4}$ & Gate may open $\mathrm{N}$ \\
\hline & Temple 19 & & & 241 & 6 & $-17 \frac{3}{4}$ & $\rightarrow$ Ponds \\
\hline & Temple 20 & & & 260 & $3 \frac{1}{2}$ & $-5 \frac{1}{2}$ & $\rightarrow$ Ponds \\
\hline & Temple 21 & & & 241 & $3 \frac{1}{2}$ & $-19 \frac{1}{2}$ & $\rightarrow$ Ponds \\
\hline & Temple 22 & & & 271 & 1 & 1 & \\
\hline & Temple 23 bis & & & $252 \frac{3}{4}$ & 1 & $-12 \frac{1}{2}$ & \\
\hline & Temple 24 & & & 244 & $3 \frac{1}{2}$ & $-17 \frac{1}{2}$ & $\rightarrow$ Ponds \\
\hline & Temple 26 & & & $336 \frac{1}{2}$ & $-0 \frac{1}{4}$ & 44 & $\rightarrow$ Serikapi \\
\hline & Temple 30 & & & 277 & 0 & 5 & \\
\hline & Temple 31 & & & $118 \frac{1}{2}$ & $2 \frac{1}{2}$ & -20 & \\
\hline & Nisantas & & & $43 \frac{1}{4}$ & $1 \frac{1}{2}$ & $34 \frac{3}{4}$ & $\rightarrow$ Yazilikaya \\
\hline & Chamber 1 (K') & & & $235 \frac{3}{4}$ & $2 \frac{1}{2}$ & -24 & $\rightarrow$ hekur-peak? $\left(\Delta \mathrm{a} \sim \frac{3 \circ}{4}\right)$ \\
\hline
\end{tabular}


Table 1 cont'd]

\begin{tabular}{|c|c|c|c|c|c|c|c|}
\hline \multirow[t]{4}{*}{ Place } & Monument & $\mathrm{L}$ & 1 & $\mathrm{a}$ & $\mathrm{h}$ & $\delta$ & Comments \\
\hline & Chamber 2 (K") & & & $353 \frac{3}{4}$ & 0 & 49 & \\
\hline & Büyükkale D & & & $131 \frac{1}{2}$ & 3 & $-28 \frac{1}{2}$ & Audience Hall \\
\hline & Büyükkale B & & & 127 & 3 & $-25 \frac{1}{2}$ & Sanctuary \\
\hline \multirow[t]{5}{*}{ Yazilikaya } & Main Hall A & $40 / 01$ & $39 / 38$ & $199 \frac{3}{4}$ & OB & $-46 \frac{3}{4}$ & \\
\hline & Corridor Hall B & & & $186 \frac{3}{4}$ & 12 & $-37 \frac{3}{4}$ & Perhaps oriented North. \\
\hline & Temple B & & & $235 \frac{1}{2}$ & 0 & -26 & \\
\hline & Main Temple & & & $316^{\frac{1}{2}}$ & 0 & $33 \frac{1}{4}$ & \\
\hline & Main Gate & & & 302 & 0 & $23 \frac{1}{2}$ & \\
\hline \multirow[t]{3}{*}{ Gavurkale } & Reliefs & 3932 & 3234 & 210 & 0 & $-42 \frac{1}{2}$ & Male pair \\
\hline & & & & $190 \frac{1}{2}$ & 0 & -50 & Sun-goddess of Arinna? \\
\hline & Royal tomb? & & & 358 & $5 \frac{1}{2}$ & $55^{\frac{3}{4}}$ & \\
\hline \multirow[t]{2}{*}{ Sarissa } & Temple I & 3925 & 3706 & $239 \frac{1}{2}$ & $?$ & $-23 \frac{1}{2}$ & \\
\hline & Teshub Temple (C) & & & 313 & $?$ & 31 & \\
\hline \multirow{5}{*}{$\begin{array}{l}\text { Eflatun } \\
\text { Pinar }\end{array}$} & Monumental Pond & 3750 & 3140 & $194 \frac{1}{2}$ & 4 & $-46 \frac{1}{4}$ & Western wall \\
\hline & & & & $193 \frac{3}{4}$ & $3 \frac{1}{2}$ & -47 & Eastern wall \\
\hline & & & & $194 \frac{1}{4}$ & $4 \frac{1}{2}$ & $-45 \frac{3}{4}$ & Shrine \\
\hline & & & & $106 \frac{3}{4}$ & $3 \frac{1}{2}$ & -11 & Northern wall \\
\hline & & & & $106 \frac{3}{4}$ & $3 \frac{1}{2}$ & -11 & Southern wall \\
\hline Aïn Dara & Shausga temple & 3622 & 3651 & 137 & 0 & -48 & In northern Syria \\
\hline
\end{tabular}

\section{GATES}

\begin{tabular}{|c|c|c|c|c|c|c|c|}
\hline \multirow{2}{*}{$\begin{array}{l}\text { Alaca } \\
\text { Hüyük }\end{array}$} & Sphinx Gate & 4014 & 3442 & $149 \frac{3}{4}$ & 1 & -41 & \\
\hline & Western Porterna & & & $267 \frac{1}{4}$ & $2 \frac{1}{2}$ & $-0 \frac{1}{4}$ & \\
\hline \multirow[t]{6}{*}{ Hattusha } & Lion Gate & 4000 & 3437 & 253 & $1 \frac{1}{2}$ & $-12 \frac{1}{4}$ & $\mathrm{~h} \sim 22_{2}^{\frac{10}{}} \mathrm{E} \quad 14_{2}^{10}$ \\
\hline & Sphinx Gate & & & 180 & $2 \frac{1}{2}$ & $-47 \frac{3}{4}$ & $\mathrm{~h} \sim-00_{2}^{\frac{10}{\circ}} \mathrm{N} 48_{4}^{3 \mathrm{o}}$ \\
\hline & Porterna & & & $0 \frac{1}{2}$ & 8 & $57 \frac{3}{4}$ & \\
\hline & King Gate & & & 110 & 2 & -14 & $\mathrm{~h} \sim 0^{\circ} \mathrm{W} \quad 14_{\frac{3}{4}}^{\circ}$ \\
\hline & Gate W & & & $310 \frac{1}{4}$ & $-0 \frac{1}{2}$ & $28 \frac{3}{4}$ & $\mathrm{~h} \sim 8 \frac{1}{2}^{\circ} \mathrm{E}-23 \frac{10}{4}^{10}$ \\
\hline & Gate $W^{\prime}$ & & & $295 \frac{1}{4}$ & $0 \frac{1}{2}$ & 19 & $\mathrm{~h} \sim 4 \frac{1}{2}^{\circ} \mathrm{E}-16^{\circ}$ \\
\hline \multirow[t]{2}{*}{ Karatepe } & SW Gate & 3718 & 3615 & $223 \frac{1}{4}$ & $4 \frac{1}{2}$ & -32 & $\frac{30}{4}^{\circ} \mathrm{NW} \& 2^{\circ} \mathrm{SE}$ \\
\hline & NE Gate & & & 31 & 2 & $44 \frac{1}{2}$ & $\begin{array}{l}33^{\frac{1}{2}} \&-32^{\circ} \\
1_{2}^{\frac{1}{2}} \mathrm{SE} \& 0_{4}^{3 \mathrm{o}} \mathrm{NW} \\
-23_{2}^{\frac{10}{2}} \& 244_{2}^{\frac{10}{0}}\end{array}$ \\
\hline
\end{tabular}

Storm-god of Hatti. ${ }^{64}$ In the case of ancient Sarissa, we do have dendrochronological dating that situates the two excavated temples of this city in the sixteenth century B.C., in the Old Hittite period. They were destroyed at the end of that period and never reconstructed. ${ }^{65}$ Unfortunately, we could not include Sarissa (modern Kuakli) in our campaign but we have listed these important data from accurate maps obtained from the bibliography. ${ }^{66}$ The table includes the data of both temples and shrines, including those associated with springs such as the Grotto in Hattusha and Eflatun Pinar, and the data of monumental gates that, as we have argued, also had a relevant ritual and symbolic character. ${ }^{67}$ Data on Hattusha's Serikale and Yenicekale are not presented since they were impossible to interpret correctly because of the state of preservation of the structures.

For the vast majority of the temples, only the ground plan of the structure preserved 


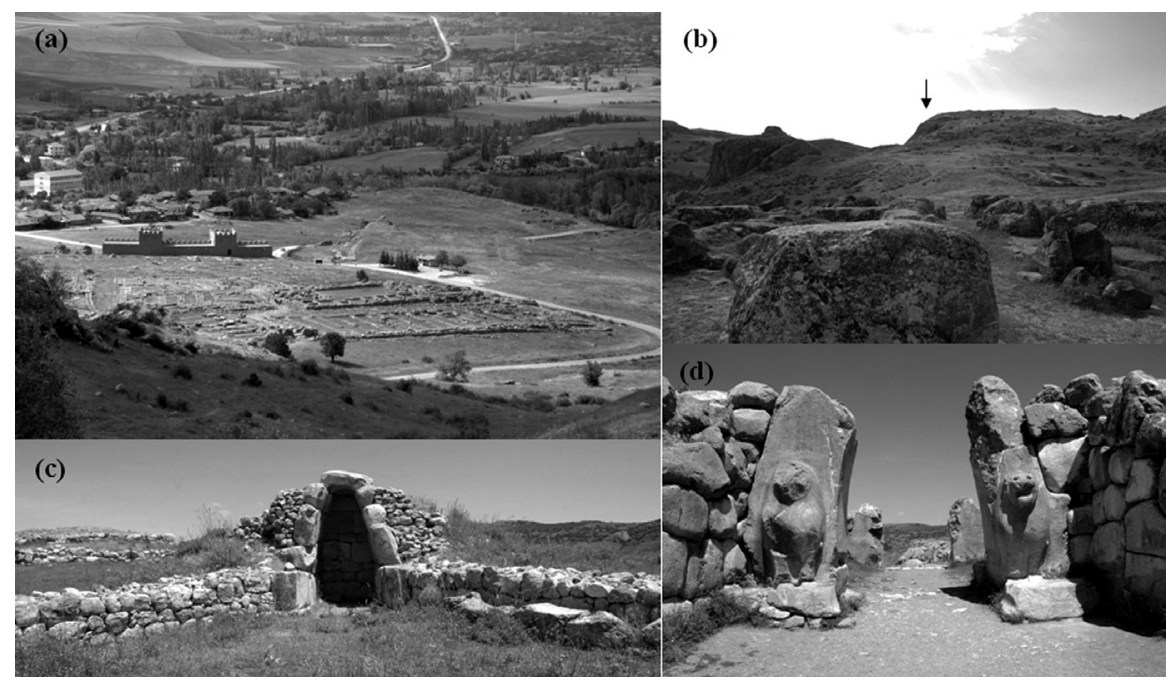

FIG. 10. Relevant images of Hattusha. (a) Temple 1 foundations and a reconstructed sector of the wall as seen from Büyükkale. $(b)$ The acropolis of Büyükkale as seen from Temple 1, showing the orientation of the temple minor axis to the northern rim of the fortified hill. (c) Chamber 1, orientated to winter solstice sunset on one of the rocky crops of the Upper City. (d) The Lions' gate, the best preserved of Hattusha's Upper City monumental gates. Photographs courtesy of Margarita Sanz de Lara.

in the stone socles, or even only the foundations, remains in situ. Consequently, we wish to stress clearly that we were not searching for extreme-precision alignments, except in those cases tested with direct observations. Bearing this in mind, and considering the large number of monuments to be studied, we have obtained our measurements using a pair of tandems (one for each author), containing a high precision clinometer and a compass (correcting for local magnetic declination ${ }^{68}$ ). Each part of the instrument permits data with a theoretical $\frac{10}{4}$ precision. However, owing to various considerations, an error close to $\frac{10}{2}$ in both azimuth and angular height is probably nearer to reality. The final data are the average of the results of the two measurements although we wish to stress that, with very few exceptions, the measurement of both authors for a certain structure were either identical or differed by less than $\frac{1}{2}$.

The majority of the data come from Hattusha (42 out of 61 independent measurements, 70\% including Yazilikaya, see Figure 6) which was not only the political capital during most of Hittite history but also the main religious centre of the empire. ${ }^{69}$ Cities like Arinna, or Zippalanda (still to be identified but certainly one of them is modern Alaca Hüyük) were also important as it was Nerik (perhaps the tell of modern Oymaağaç) whose festivals, including the important purulli, were moved to Hattusha when this sacred city was lost to the Kaskeans in the fourteenth century B.C. ${ }^{70}$ Our data also come from the sacred village of Alaca Hüyük, the palatial city 
of Shapinuwa (modern Ortaköy), ${ }^{71}$ or the Iron Age "fortress" of Karatepe, further south in the mountains of Cilicia. The Aïn Dara datum, in northern Syria, was taken in an early visit to this country in 1996. Table 1 data of Hattusha and other sites also show some alternative orientations for several buildings, such as the secondary axis of Temple 1 or those of monumental gates in the opposite direction (from the outside looking in, see Figure 10), which will be relevant in the following discussion. However, these are not included as independent measurements in Figures 11 and 12.

Figure 11(a) shows the orientation diagram of Hittite monuments, distinguishing temples and shrines from monumental gates. In either case, a first inspection of the diagram would illustrate Seeher's argument cited in our epigraph: "no special direction of the compass seems to have been preferred for the orientation of the temples." There are monuments, both temples and monumental gates, orientated in all directions. However, a closer inspection of the diagram shows a clear concentration of alignments near to the solstices, or even some of the cardinal directions. Clearly this fact deserved further investigation. The result of this next step is Figure 12(a), where the declination histogram (which is independent of geographical location and local topography) is presented. The histogram presents astronomical declination versus a new form of calculating the normalized frequency, permitting a clearer and cleverer determination of a certain peak degree of significance within the histogram. ${ }^{72}$

Four main peaks, and a satellite, have a degree of confidence higher than $99 \%$. Interestingly, the highest one is centred at a declination of $-24^{\circ}$ (our declination values will have an average error of $\pm_{4}^{30}$ ) which should be reasonably correlated with the winter solstice sun (a good example is Chamber 1, see Figure 10). The second one is centred at $0 \frac{1}{4}^{\mathrm{o}}$ and could be catalogued as 'equinoctial'. A third peak is a declination of $-48^{\circ}$, which considering the latitudes of most Hittite centres, close
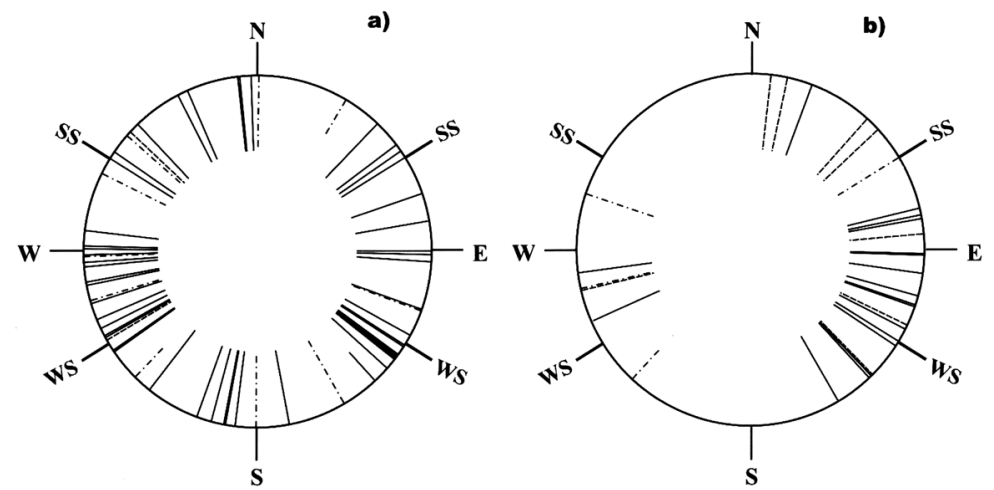

FIG. 11. Orientation diagrams of (a) 61 alignments in Hittite monuments, and (b) 31 alignments in Phrygian monuments, from data in Tables 1 and 2. For the Hittites, solid lines stand for temples and dot-dashed lines for monumental gates. Short lines refer to Neo-Hittite monuments of the Iron Age. For the Phrygian, solid lines stand for step-monuments, dashed lines for façades, and dotdashed lines for temples, while the short line stands for the Augustus and Roma temple in Ankara. 


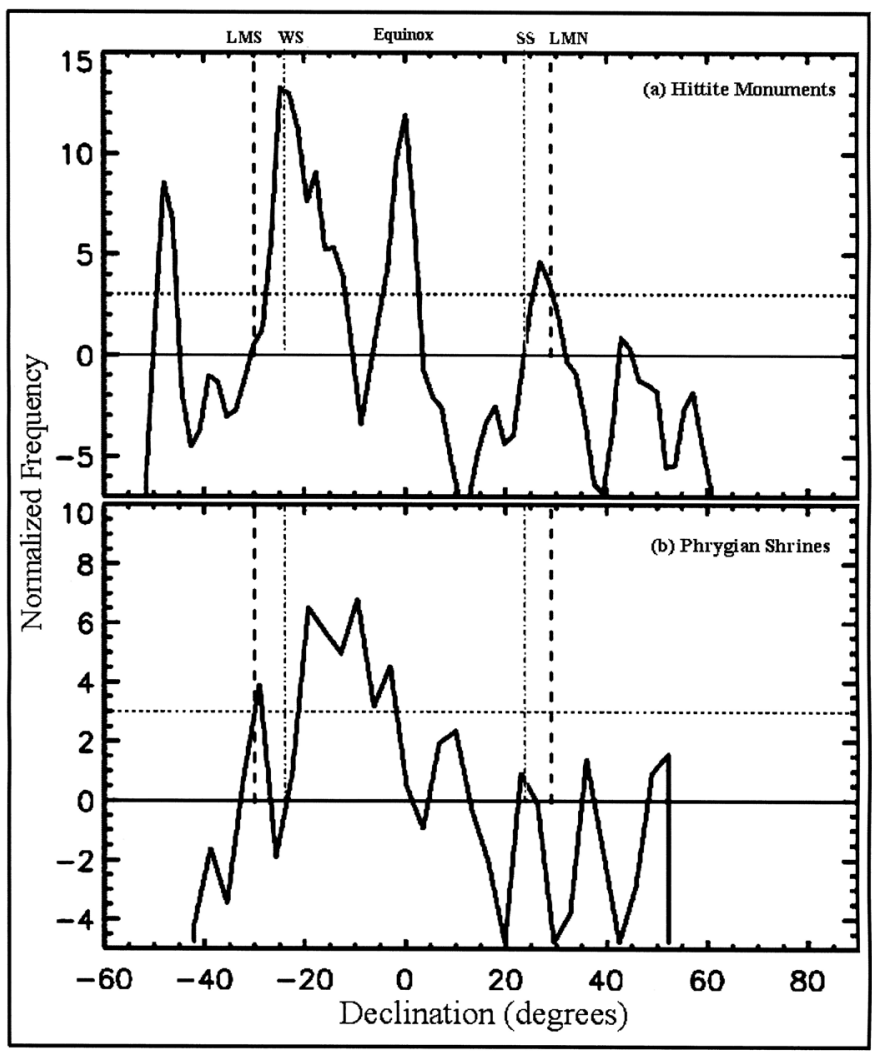

FIG. 12. Declination histogram of ( $a$ ) Hittite and (b) Phrygian monuments. Hittite monuments have several statistically significant peaks above the $3 \sigma$ level with a marked astronomical meaning, either meridian, equinoctial, or solstitial. In Phrygia, significant peaks are within the luni-solar range. Dashed lines stand for the declinations of the extreme positions of the moon (the lunastices) and dot-dashed lines for those of the solstices. See the text for further discussion.

to $40^{\circ} \mathrm{N}$, is certainly a peak of accumulation associated with meridian alignments. The following peak is at a declination of $27^{\circ}$ and is located nearly at the middle of the extreme northern declinations of the sun at the summer solstice, $c .24^{\circ}$, and the moon at major lunastice, $c$. $28 \frac{1}{2}$. The planet Venus's extreme northern declination is another suggestive alternative. Finally, there is the satellite peak at $-17 \frac{30}{4}$, surprisingly matching the declination of Sirius, the brightest star in the Anatolian sky in the thirteenth century B.C. ${ }^{73}$ Thus, every single significant peak in our histogram has a simple, straightforward astronomical explanation. 


\subsection{The Solar Paradigm}

The most significant peaks in our declination histogram are certainly solar, in agreement with the importance of Hittite solar cults and solar rituals, as analysed in Section 1.1. In addition, an implicit recognition of the solstices by the ancient Hittites could be addressed in certain hymns to the sun divinity. At a certain stage, the text reads, ${ }^{74}$ "thou stridest through the four eternal corners", where these "corners" could be interpreted as the four extreme positions on the horizon reached by the rising and setting sun at the solstices.

The winter solstice seems overwhelmingly dominant. We could find an explanation of its importance in the winter festival of the Sun-goddess of Arinna. With due caution, we could even imagine that temples having this orientation could be somehow associated to the Sun-goddess. However, this is a risky suggestion and should be regarded as very tentative.

There is, however, a case study of much interest and this is her main sanctuary at Hattusha, Temple 1. From the central courtyard of this building (or from the temple ceiling, where, as we have learnt, the king appealed to the solar deities) and along the temple minor axis to the east, the sun-disc would have been seen at dawn climbing the northern rim of Hattusha acropolis, where a small temple of the goddess was located, on dates close to the winter solstice (see Table 1 and Figure 10).

The summer solstice is less evident but there is a suggestive case, Yazilikaya. Figure 4 shows summer solstice sunset on the axis of the monumental gate of the sanctuary. Sunset takes place on a distant hill which is, curiously, the same as that towards which the secondary axis of Hattusha's Lower City Temple 1 is facing when looking west. Sunset is to be connected with the earthly aspect of the Sun-goddess and this would be logical for a mortuary shrine. This character would be reinforced by an intriguing hierophany described by Jürgen Seeher. ${ }^{75}$ At the beginning of summer, and for just a short time in late afternoon, the light of the descending sun illuminates the image of Tudhaliya IV in Hall A of the sanctuary, while the rest of the year it stays in shadow. This is certainly a summer solstice phenomenology and could be connected to the main gate orientation and to the funereal aspect of this rock shrine. ${ }^{76}$

We also noted on site that Tudhaliya's hekur-peak at Nisantas was orientated towards Yazilikaya (see Table 1), reinforcing the connection between the two sanctuaries. However, no distinguishing astronomical orientation could be established in this case, topography probably being the single and necessary nexus.

The 'equinoctial' peak in Figure 12 is caused by a series of temples orientated nearly due-east or due-west, such as the impressive Temples 2 and 3 or Temples 8 and 22, respectively, plus some additional sacred buildings facing declinations close to the equinoctial one such as Temples 17 and 30. This pattern could be an indication of an interest in sunrise or sunset on dates close to the autumn and spring equinoxes. In Section 1.3, we have shown that the most important Hittite festivals, AN.TAH. SUM and nuntarriyashas, were celebrated in spring and fall, respectively. It might be possible that a phenomenon close to the equinoxes (if not the equinox itself, 
whichever definition we may select) acted as the respective heralds of the festivals (and perhaps of the New Year, at least after the reign of Mursili II) and temples were orientated accordingly. But this hypothesis offers another striking possibility.

The Upper City of Hattusha contained no fewer than thirty temples, built from the early empire to the reign of Suppiluliuma II, ${ }^{77}$ suggesting that its splendid fortifications, with at least three decorated monumental gates, had not only a secular function but also a ritual one that could be connected to Hittite festivals and processions. ${ }^{78}$ This idea could be reinforced by the fact that the axes of the three major city gates apparently converged at a certain point of the Upper city close to Nisantas, ${ }^{79}$ although our archaeoastronomical measurements are still more interesting. They show (see Table 1) that the impressive Yerkapi (the Sphinx gate and associated structures) is accurately orientated in the meridian direction, suggesting that the north-south axis of the city was known with high precision and was possibly related to certain cultural aspects.

However, the most interesting case is that of the Lion and King Gates. These monumental accesses to the Upper City were orientated in such a way (declination of $c .14 \frac{1}{2}$ when looking in, see Table 1) that on a certain day in the end of April or the very beginning of May (within the prolectic Gregorian calendar), sunrise could have been observed in the eastern hills from the outside of the Lion gate (see Figure 10) and sunset in a distant horizon from the outside of the King Gate. There are two important questions related to this date. On the one hand, this is the epoch of Beltane, the main spring festival of the Iron Age and later Celts. Hence, considering the Indo-European ancestry of the Hittite ruling class, we might establish a striking parallelism. On the other hand, there is a period of around 40 days between the spring equinox (20 to $22 \mathrm{March}$ ) and the date of Beltane, which closely resembles the duration of the AN.TAH.SUM festival. Consequently, it is probable, although not certain, that this major festival lasted from the spring equinox to classic 'Beltane', whatever the significance that these two important time-marks might have had in the Hittite mentality. ${ }^{80}$ However, astronomy may offer yet another fascinating possibility.

\subsection{Dealing with Stars?}

In the fourteenth and thirteenth centuries B.C., during the apogee of the Hittite Empire, the Pleiades had their heliacal setting in central Anatolia on dates close to 20 March, within a margin of one day, depending on the precise atmospheric conditions, while its heliacal rising was close to 3 May; so the asterism was invisible for a period close to six weeks (nearly 40 days). The importance of the Pleiades within ancient Mesopotamian calendrics is well known and we have already discussed their relation to the purulli festival, presumably celebrated within the AN.TAH.SUM or a short time after "when the land prospers and thrives" (scholars take different views of this, see Section 1.3). Hence, the period of Pleiades invisibility could also be connected to the length of the AN.TAH.SUM festival, and some related astronomical phenomena, such as the Pleiades's heliacal setting or their conjunction with the new crescent (as was customary further south in the land between the two rivers), could have acted as an 
alternative herald of the annual lunar cycle and the festival calendar. The possibility of stellar observations opens the way to other interesting hypotheses.

Figure 9 shows images of three Hittite sites, built or decorated on a monumental scale, where a funereal character has been recognized (see Section 1.4). Two are artificial rooms built on a cyclopean scale, the northern chamber at Gavurkalesi and Chamber 2 at the Südburg of Hattusha. The third is Hall (or chamber) B of Yazilikaya where a combination of natural (the corridor between vertical rock walls) and artificial (the decorations and some minor dry-stone works) elements is evident. Interestingly, all three 'chambers' are open towards an azimuth close to geographical north (see Table 1). Hence, the coherence of the sample suggests a common purpose that could perfectly well be connected with either a burial or a funereal commemorative character, or both. North-orientated burial monuments are not atypical in eastern Mediterranean Copper and Bronze Age periods, the pyramids being a paradigm. In these cases, an orientation to a northern constellation, asterism (such as the Plough) or star is often claimed. ${ }^{81}$

Unfortunately, our knowledge about ancient Hittites star-lore is extremely scarce, or even non-existent in the case of the northern constellations. For example, in the particular case of the Plough, the neighbours of the Land of Hatti in the epoch of the empire recognized a bull's foreleg (or a complete bull) in the case of ancient Egyptians, a chariot or wagon (normally assigned to the weather god Enlil, located in nearby Böotes) in the case of the Sumerian tradition inhabitants of Mesopotamia, and either a bear or a chariot in the case of the Achaeans. ${ }^{82}$

We have seen in Figure 4 that the bulls of Teshub (i.e. the Hurrian interpretation of the Storm-god of Hatti), Serri and Hurri, were the handlers of the sky, a duty most likely to be performed near the celestial pole. It should be expected that the chariot of the god would be nearby. Besides, as we have discussed, a slaughtered ox was used as an intermediary in the funerals of Hittite kings, a fact resembling similar Egyptian rituals related to the 'opening of the mouth' ceremony. Hence, we could imagine that Teshub's chariot and its yoke of draught bulls could have been seen by the ancient Hittites in the northern realms of the celestial sphere. Consequently, if the monuments depicted in Figure 9 were indeed royal mausoleums, their appropriate northern orientation would have helped the soul of the king to pursue his final expectation: that of ascending to dwell with the gods of heaven. ${ }^{83}$ This is indeed a fascinating possibility that should be further explored in the mythological texts. ${ }^{84}$

In the same line of argument, Temple 5 has been interpreted as a temple dedicated to the ancestors of the Hittite royal family. ${ }^{85}$ However, its orientation, independent of any other pattern described so far, cannot confirm or refute this hypothesis.

We should finally discuss the satellite peak, at a declination of $-17 \frac{30}{4}$, perhaps related to Sirius. In Section 1.1 we proposed as an alternative hypothesis that the astral god Pirinkir could be identified with a bright star. Sirius was well known in contemporaneous Egypt as the 'Star of Isis', who, through her identification with Hathor, could be related to the goddess of love aspect of Hurrian Ishtar, or Shausga. Hence, we speculate that the term ISTHAR.MUL associated with Pirinkir (see Section 
1.1) could be read as the Star of Isthar-Shausga-Hathor-Isis and, consequently, with the brightest star in the Hittite skies, Sirius. However, as we insisted before, this idea should be considered with caution until new textual or epigraphic evidence can confirm or refute it.

\section{THE PHRYGIAN PARADIGM}

The Phrygian Kingdom was the Iron Age successor of the Hittite Empire in the lands of central Anatolia (see Figure 1). Between the tenth and the sixth centuries, they created an advanced literate culture, building temples for their deities, worshipping their main goddess Matar in open air (mostly rock-cut) sanctuaries, and burying their kings, often named Mita (or Midas), in monumental tumuli close to their capital city, Gordios. ${ }^{86}$

In a recent book dedicated to Phrygian rock-cut shrines, the archaeologist Sussane Berndt-Ersöz proposes and performs a complete, erudite and up-to-date study of these monuments (which are fascinating but generally ignored by the great public), including an analysis of their orientations. ${ }^{87}$ In the book, the author gives a profound description of step monuments, idols, niches and the often impressive Phrygian façades, analysing their historical, chronological and topographical context. ${ }^{88}$

Step monuments and façades are by far the most interesting of Phrygian rockcut shrines. Idols are often related to step monuments and to niches, which are also related to rock-cut tombs. The majority of step monuments have been dated to the Middle Phrygian period (c. 800-550 B.C.), including most of the monuments in Midas Sehri (the City of Midas) in central Phrygia (see Figure 13). ${ }^{89}$ In contrast, most of the decorated façades have been dated to the period when Phrygia was under Lydian domination in the mid-sixth century B.C. Figure 14 shows a pair of impressive façades, illustrating their typology and topography.

Berndt-Ersöz ends her analysis of the orientation of step monuments by concluding that the majority of step monuments faced either east or south-east. This is well illustrated in the histogram presented in Figure 15, where we have made an improved adaptation of her original diagrams. However, a problem arises here, actually a general problem in many archaeological reports. Her orientation diagrams (and the adapted histogram) are somewhat misleading and certainly off-putting for a dedicated archaeoastronomer. Instead of numbers, i.e. azimuths, the histogram shows general and prosaic cardinal point information such as east (E), south-west (SW) or east-south-east (ESE), with a bandpass as large as $22 \frac{10}{2}$ and so useless from an astronomical point of view. This means that the second most significant peak of Figure 15 at SE could include solar orientations close to the winter solstice sunrise (especially if we are dealing with a rough horizon), lunar orientations close to the major southern lunastice, or orientations that could be interpreted as stellar rising or as a prosaic sun- or moon-climbing. The information is thus absolutely confusing.

When planning the Hittite prospection campaign, we notice that it would be easy (and not very expensive of time and resources) to include some of the most important 


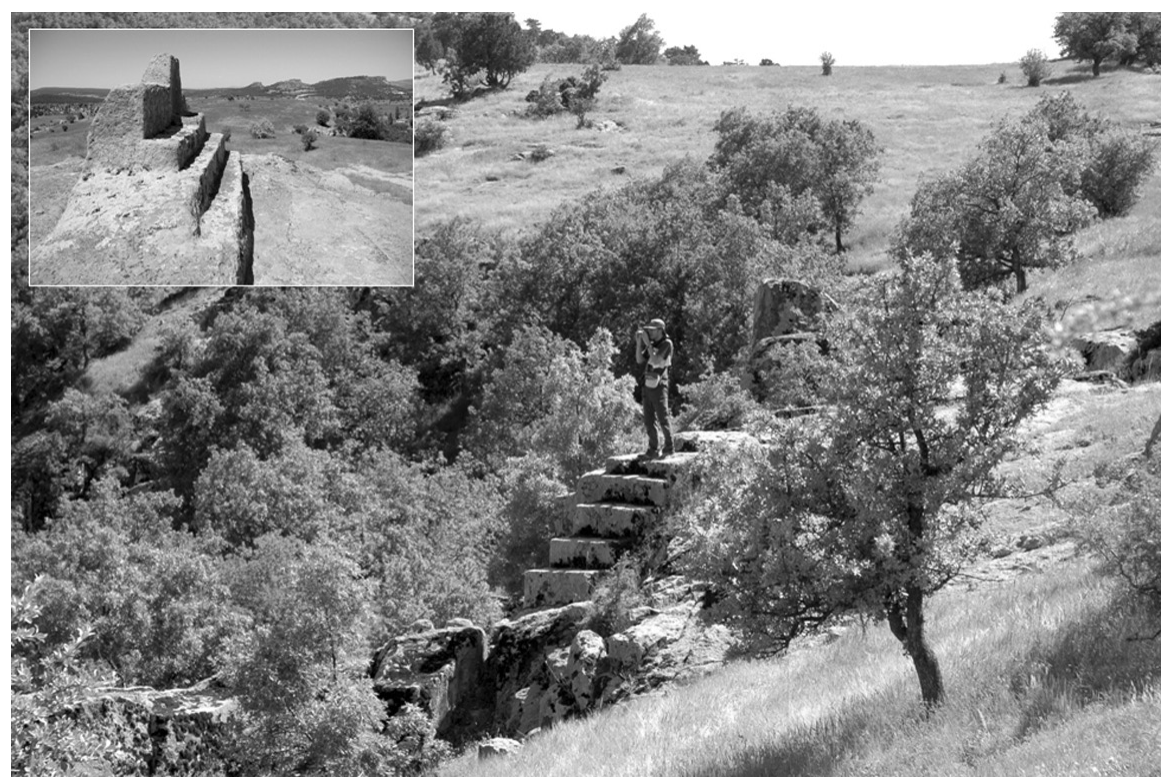

FIG. 13. Step-monuments in Midas Sehri. The first author stands on no. 67, to give a sense of scale, and detail of no. 70 (top-left), which includes a nearly erased Phrygian inscription and a couple of circular idols. The two monuments are typically aligned in the sunrise direction. Photographs courtesy of Margarita Sanz de Lara.

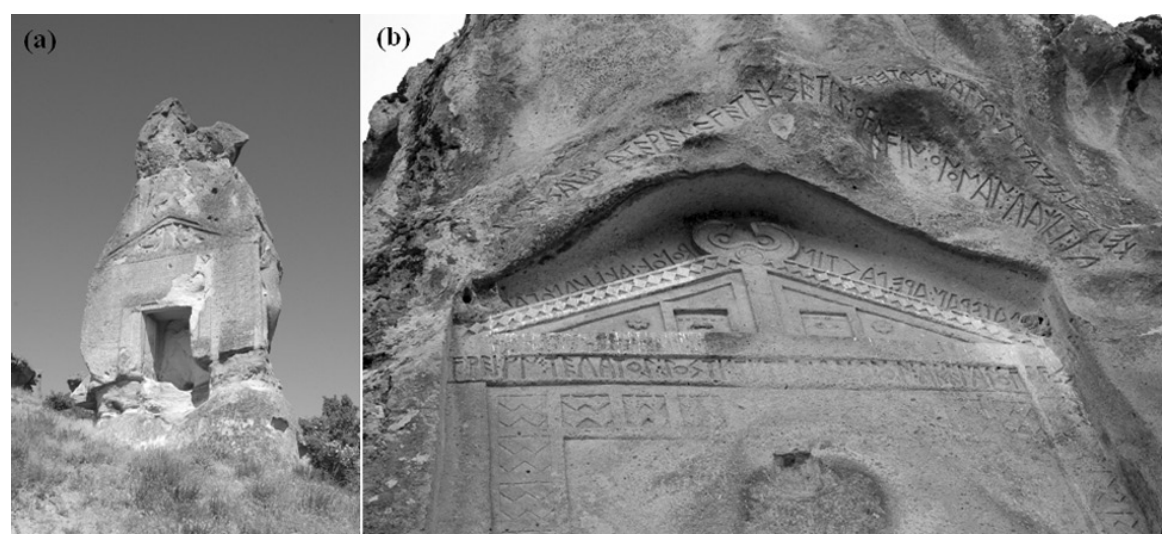

FIG. 14. Arslankaya (a), near Döger, and Areyatis (b), near Midas Sehri, two splendid examples of Phrygian façades. The former included a niche with an erased figure of the mother goddess Matar and the latter one of the best preserved Phrygian inscriptions. Photographs courtesy of Margarita Sanz de Lara $(a)$ and Juan Antonio Belmonte $(b)$. 


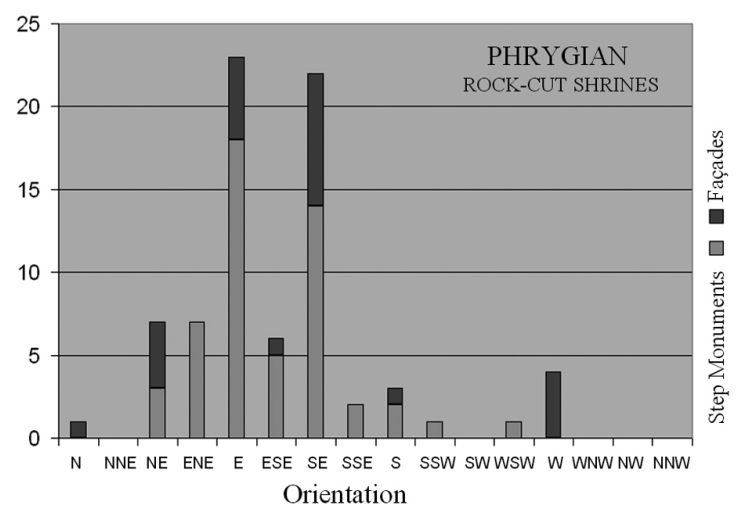

FIG. 15. Orientation histogram of Phrygian step-monuments and façades from data taken from the work of Sussane Berndt-Ersöz. ${ }^{5}$ This should be compared with our declination histogram in Fig. 12(b). See the text for further discussion.

Phrygian settlements such as those in the Kohnus Valley or in the acropolis and surroundings of Midas Sehri. This would serve to test Bernt-Ersöz's work astronomically and to compare Hittite outcomes with those provided by the culture occupying nearly the same space in central Anatolia during the Iron Age, after the final fall of the Hittite Empire. ${ }^{90}$ The places visited in our campaign-addendum are specified in Figure 1 and the measurements are presented in Table 2.

Our sample includes 19 step monuments and 8 façades. This is more than a third $(\sim 36 \%)$ of the step monuments and façades studied by Bernt-Ersöz. This is indeed significant enough to get a first insight into the Phrygian monuments. Additionally, we include the datum of the temple of Matar at Pessinus, built in the Roman period, but perhaps over an earlier Phrygian shrine, and that of the temple of Roma and Augustus in Ankara (not included in the overall analysis). Finally, data for the ancient Phrygian capital, Gordios, are included. However, only the datum of Megaron 4, which has been identified as a possible temple, ${ }^{91}$ and an altar have been included in the general analysis.

The orientation diagram for our data is presented in Figure 11(b), where step monuments and façades are distinguished. Nearly $90 \%$ of the step monuments are within the lunisolar range, clearly suggesting an astronomical justification for the orientation of these structures. Figure 12(b) shows the declination histogram of the data, permitting a precise analysis of our sample. In this case, only a set of peaks within the solar (or lunar) range of declinations and an isolated peak at $-29^{\circ} \pm_{4}^{30}$, nearly the minimum declination of the moon (major lunastice), are significant to the $99 \%$ level. This demonstrates that the loosely original 'south-east' orientations can easily be reinterpreted in the light of our data as orientations with astronomical significance. Also, Gordios, the Phrygian capital, seems to have been planned through a major alignment, offering orientations towards summer solstice sunrise for buildings, sacred 
TABLE 2. Orientation of Phrygian monuments (temples, step-monuments (S) and façades (F)) as obtained in our mission in central Anatolia in June 2009. The table shows for each monument the location, the identification of the temple (either the most common name, the owner deity, or the builder), the latitude and longitude ( $\mathrm{L}$ and l), the azimuth (a) from inside looking out, the angular height of the horizon $(\mathrm{h})$ in that direction, and the corresponding declination $(\delta)$. The last column contains additional comments.

\begin{tabular}{|c|c|c|c|c|c|c|c|}
\hline Place & Monument & $\mathrm{L}$ & 1 & a & $\mathrm{h}$ & $\delta$ & Comments \\
\hline \multirow[t]{2}{*}{ Karahisar } & Small Sun Altar & $40^{\circ} 16^{\prime}$ & $34^{\circ} 42 \frac{3}{4}$ & $91 \frac{1}{2}^{\circ}$ & $-0 \frac{1}{2} \circ$ & $-2^{\circ}$ & $S$ \\
\hline & Large Altar & & & 117 & 0 & $-20 \frac{3}{4}$ & $\mathrm{~S}$ \\
\hline Ankara & August Temple & 3952 & 3252 & $222 \frac{3}{4}$ & 0 & $-34 \frac{3}{4}$ & $\begin{array}{l}\text { Phrygian } \\
\text { origin? }\end{array}$ \\
\hline \multirow[t]{12}{*}{ Gordios } & Megaron 1 & 3939 & 3159 & 62 & 1 & $21 \frac{1}{2}$ & \\
\hline & Megaron 2 & & & 61 & 1 & 22 & \\
\hline & Megaron 3 & & & $59 \frac{3}{4}$ & $1 \frac{1}{2}$ & $23 \frac{1}{2}$ & \\
\hline & Megaron 4 & & & $58 \frac{1}{2}$ & $1 \frac{1}{2}$ & $24 \frac{1}{2}$ & $\begin{array}{l}\text { Possible } \\
\text { Temple }\end{array}$ \\
\hline & Altar & & & 59 & $1 \frac{1}{2}$ & 24 & $\mathrm{~S}$ \\
\hline & From sacred area ... & & & $63 \frac{1}{2}$ & $1 \frac{1}{2}$ & 21 & $\rightarrow$ Hill NE \\
\hline & & & & $77 \frac{1}{4}$ & 1 & 10 & $\rightarrow$ Midas \\
\hline & & & & 121 & 2 & $-22 \frac{1}{4}$ & $\begin{array}{l}\text { Tumulus } \\
\rightarrow \text { Double } \\
\text { Hill SE I }\end{array}$ \\
\hline & & & & $122 \frac{1}{2}$ & $1 \frac{3}{4}$ & $-23 \frac{3}{4}$ & $\rightarrow$ Double \\
\hline & & & & $124 \frac{1}{2}$ & 2 & $-24 \frac{3}{4}$ & $\begin{array}{l}\text { Hill valley } \\
\rightarrow \text { Double } \\
\text { Hill SE II }\end{array}$ \\
\hline & M10 & & & 257 & $0 \frac{1}{2}$ & -10 & Hill SW \\
\hline & & & & 77 & $\frac{3}{4}$ & $10 \frac{3}{4}$ & $\begin{array}{l}\text { to Midas } \\
\text { Tumulus }\end{array}$ \\
\hline Pessinus & Matar Temple & 3920 & 3135 & $288 \frac{1}{2}$ & $1 \frac{1}{2}$ & 15 & \\
\hline \multirow[t]{18}{*}{ Midas Sehri } & $\mathrm{N}^{\mathrm{o}} 30$ Midas Tomb & 3912 & 3042 & 85 & 0 & $3 \frac{1}{2}$ & $\mathrm{~F}$ \\
\hline & $\mathrm{N}^{\circ} 31$ Hyacinth & & & 47 & $0 \frac{1}{2}$ & 36 & $\mathrm{~F}$ \\
\hline & $\mathrm{N}^{\mathrm{o}} 34$ "Gordios" Tomb & & & $256 \frac{3}{4}$ & 0 & $-10 \frac{1}{2}$ & $\mathrm{~F}$ \\
\hline & $\mathrm{N}^{\mathrm{o}} 64$ & & & $78 \frac{1}{4}$ & $-0 \frac{1}{4}$ & $8 \frac{1}{2}$ & $\mathrm{~S}$ \\
\hline & $\mathrm{N}^{\circ} 67$ & & & 80 & $-0 \frac{1}{4}$ & 7 & $\mathrm{~S}$ \\
\hline & $\mathrm{N}^{\mathrm{o}} 68$ & & & 136 & $6 \frac{1}{2}$ & -29 & $\mathrm{~S}$ \\
\hline & $\mathrm{N}^{\circ} 69$ & & & 137 & $6 \frac{1}{2}$ & $-29 \frac{1}{2}$ & S Inscription \\
\hline & $\mathrm{N}^{\circ} 69(\mathrm{H})$ & & & $123 \frac{1}{2}$ & 4 & -23 & S Throne \\
\hline & $\mathrm{N}^{\mathrm{o}} 70$ & & & $108 \frac{1}{2}$ & 0 & $-14 \frac{1}{2}$ & $\mathrm{~S}$ \\
\hline & $\mathrm{N}^{\mathrm{o}} 75$ & & & $121 \frac{1}{4}$ & 8 & -18 & $\mathrm{~S}$ \\
\hline & $\mathrm{N}^{\mathrm{o}} 76$ & & & $76 \frac{1}{2}$ & 1 & $10 \frac{3}{4}$ & $\mathrm{~S}$ \\
\hline & $\mathrm{N}^{\mathrm{o}} 77$ Agditis Temple & & & $105 \frac{1}{2}$ & $4 \frac{1}{2}$ & -9 & $\mathrm{~S}$ \\
\hline & $\mathrm{N}^{\circ} 82$ & & & $262 \frac{1}{2}$ & 0 & $-6 \frac{1}{4}$ & $\mathrm{~S}$ \\
\hline & $N^{0} 85$ & & & 246 & 2 & $-17 \frac{1}{4}$ & $\mathrm{~S}$ \\
\hline & $\mathrm{N}^{\circ} 86$ & & & $149 \frac{1}{4}$ & 4 & $-38 \frac{1}{2}$ & $\mathrm{~S}$ \\
\hline & $\mathrm{N}^{\mathrm{o}} 88$ & & & 92 & 0 & -2 & $\mathrm{~S}$ \\
\hline & Sector M (No 89-92) & & & $108 \frac{1}{4}$ & $2 \frac{1}{2}$ & $-12 \frac{1}{2}$ & $\mathrm{~S}$ \\
\hline & Areyatis & 3913 & 3042 & 42 & $2 \frac{1}{2}$ & 37 & $\mathrm{~F}$ \\
\hline \multirow[t]{3}{*}{ Döger } & Arslankaya & 3906 & 3025 & $115 \frac{3}{4}$ & 2 & $-18 \frac{1}{2}$ & $\mathrm{~F}$ \\
\hline & Kapikaya II & & & $6 \frac{1}{2}$ & 2 & 52 & F Image \\
\hline & & & & $20 \frac{1}{2}$ & 2 & $48 \frac{1}{4}$ & $\mathrm{~S}$ \\
\hline \multirow[t]{3}{*}{ Kohnus Valley } & Arslantas & 3903 & 3031 & 12 & 3 & 52 & $\mathrm{~F}$ \\
\hline & Talmash & 3902 & & 136 & 4 & -31 & $\mathrm{~F}$ \\
\hline & $\mathrm{N}^{\mathrm{o}} 58$ & 3902 & & 98 & 2 & -5 & $\mathrm{~S}$ \\
\hline
\end{tabular}


or profane, built with an axis perpendicular to this alignment (see Table 2). Certain Hittite Late Bronze Age practices could therefore have survived during the Iron Age.

A parallel could be established between Phygian Matar and the Sun-goddess (either of Arinna or of the Earth) of the Hittites. However, the astral nature of Matar is far from clear and, in fact, when the interpretatio Graeca was applied to this deity, she tended to be identified with the moon and not with the sun. This would explain the peak at the major lunastice. Evidently, astronomical orientations were still pursued in the region during the Phrygian period, but the heavenly body of reference was possibly changed.

The Phrygian data are indeed incomplete and more precise measurements (where azimuths and horizon angular heights are the numbers to be obtained) are highly desirable. Our small excursus has served to demonstrate the potential of Phrygian sacred structures, notably the rock-carved shrines, for archaeoastronomical studies, but it needs to be completed in the future through investigation of other minor and major Phrygian sites. ${ }^{92}$

\section{CONCLUSIONS}

To our knowledge, this is the first work dedicated to cultural astronomy studies of the Hittite civilization. In this respect, we have analysed in depth the bibliographical sources, including the original texts. ${ }^{93}$ Most importantly, however, our fieldwork has yielded data for nearly a hundred sacred structures erected by ancient Anatolian civilizations such as the Hittite and the Phrygians. Our main conclusions can be summarized as follows:

(i) The importance of solar cults has been clearly emphasized. Our data confirm the textual evidence and show the relevance of solstitial and 'equinoctial' orientations that could be explained within the context of ancient Hittite cult necessities.

(ii) We have explored the ancient Hittite sacred time. The relationship of relevant orientations with certain key moments in the annual solar cycle, such as the solstices, the equinoxes or perhaps the quarter-season days, should be accommodated within this framework.

(iii) Hattusha presents a striking and highly interesting astronomical and topographical landscape. Potential relationships between astronomical phenomena, structures such as temples and monumental gates, and various elements of the local landscape have been illustrated.

(iv) The connection between certain structures, tentatively classified as having a funereal character, and their meridian orientation has been established. Whether or not this could be justified within a Hittite mythological and sky-lore context will need confirmation.

(v) Finally, a preliminary analysis of a still incomplete but statistically significant sample of monuments has confirmed the predominantly lunisolar orientation pattern 
of rock-cut Phrygian shrines.

With its measurement of the orientation of more than 60 structures on sites all around Anatolia, ours is by far the most ambitious project of this class ever attempted for the study of the astronomical aspect of the ancient Hittite civilization. Our intention has been to put archaeoastronomy on the correct footing it deserves within Hittitological studies. A new campaign in other regions of Anatolia, such as specific sites in the area of Kayseri (Kusakli-Sarissa or Kanesh-Nesha), ${ }^{94}$ where a handful of temples are still waiting to be measured, and other minor monuments scattered in the region, ${ }^{95}$ would be desirable in the near future. We hope that study of these structures will reinforce the idea, stated for the first time in this paper, that the ancient Hittites orientated their temples according to their celestial (and to a lesser extent terrestrial) landscape.

\section{ACKNOWLEDGEMENTS}

We wish to express our acknowledgement to the cultural astronomer Edwin Krupp, the oriental and classic language scholar Doris Vickers and the Celtic study specialist Marco García Quintela for their encouragement of our work and their useful comments. We would like to express our gratitude to Margarita Sanz de Lara for her excellent images. This work is partially financed under the framework of the projects P310793 “Arqueoastronomía” of the IAC, and AYA2007-60213 “Orientatio ad Sidera II" of the Spanish MICINN.

\section{REFERENCES}

1. A comprehensive summary of the Egyptian results can be found in J. A. Belmonte, M. Shaltout and M. Fekri, "Astronomy, landscape and symbolism: A study on the orientations of ancient Egyptian temples", in In search of cosmic order: Selected essays on Egyptian archaeoastronomy, ed. by J. A. Belmonte and M. Shaltout (Cairo, 2009), 211-82.

2. T. Bryce, The kingdom of the Hittites (King's Lynn, 2005).

3. See, for example, E. C. Krupp, "Bedroom politics and celestial sovereignty", in Current studies in Archeo-astronomy, ed. by J. W. Fountain and R. M. Sinclair (Durham, 2005), 413-29.

4. J. Seeher, Hattusha-guide, a day in the Hittite capital (Istanbul, 2006), 80.

5. S. Berndt-Ersöz, Phrygian rock-cut shrines (Leiden, 2006).

6. See T. Bryce, Life and society in the Hittite world (King's Lynn, 2002), for a discussion on the topic. For the Luwians, see H. C. Melchert (ed.), The Luwians (Boston, 2003).

7. On the religion of the Hittites, see H. A. Hoffner Jr, "Hittite religion", in Encyclopedia of religion, ed. by M. Eliade, vi (Chicago, 1987), 408-14; G. M. Beckman, "The religion of the Hittites", The biblical archaeologist, lii (1989), 98-108; V. Haas, Geschichte der hethitischen Religion (Leiden, 1994); M. Hutter, "Religion in Hittite Anatolia. Some comments on Volkert Haas: Geschichte der hethitischen Religion", Numen, xliv (1997), 74-90; and the most recent, P. Taracha, Religions of second millennium Anatolia (Wiesbaden, 2009). For the religion of the Luwians, see M. Hutter, "Aspect of Luwian religion", in The Luwians, ed. by Melchert (ref. 6), 211-80.

8. Taracha, op. cit. (ref. 7), 33.

9. According to I. Singer, "The thousand gods of Hatti: The limits of an expanding pantheon", Israel oriental studies, xiv (1994), 81-102. The Hittite one was an expanding pantheon as conquests evolved in time and space. See also Taracha, op. cit. (ref. 7), 84-92.

10. Bryce, op. cit. (ref. 6), 139-49. 
11. For comprehensive lists of the Hittite pantheon, see Taracha, op. cit. (ref. 7), 27-31, 39-50 and 84-95. For the Sun-goddess, see H. G. Güterbock, "The composition of Hittite prayers to the sun”, Journal of the American Oriental Society, 1xxviii (1958), 237-45; Hutter, op. cit. (ref. 7, 1997), 80; and Taracha, op. cit. (ref. 7), 47-54.

12. B. J. Collins, The Hittites and their world (Atlanta, 2007), 174-7.

13. Taracha, op. cit. (ref. 7), 88-90; and Collins, op. cit. (ref. 12), 97-9.

14. G. Kellerman, Recherche sur les rituels de foundation hittites (Paris, 1980), 108-13. For Hattushili, see Ph. H. J. Houwink ten Cate, "The Sun God of Heaven: The assembly of the gods and the Hittite king", in Effigies Dei: Essays on the history of religion, ed. by D. van der Plas (Leiden, 1987), 13-34.

15. Collins, op. cit. (ref. 12), 172. See also Houwink ten Cate, op. cit. (ref. 14).

16. Collins, op. cit. (ref. 12), 19. It is also worth noting that within the substitute king ritual context during a solar eclipse, at sunrise the replaced true king daily kneels before the Sun God of Heaven, praying to be relieved from his now, as an ordinary mortal, inevitable future residence among the shades: Houwink ten Cate, op. cit. (ref. 14).

17. Taracha, op. cit. (ref. 7), 43 and 110.

18. Taracha, op. cit. (ref. 7), 146.

19. For Shausga in general, see C. Burney, Historical dictionary of the Hittites (Lanham, 2004), 239; Bryce, op. cit. (ref. 6), 146-7; and Taracha, op. cit. (ref. 7), 119-28. For Shausga as Venus, see Krupp, op. cit. (ref. 3).

20. G. Beckman, "The babilili-ritual from Boğazköy (CTH 718)", in Recent developments in Hittite archaeology and history, ed. by K. Aslihan Yener, H. A. Hoffner Jr, and S. Dhesi (Winona Lake, 2002), 35-42. See also Taracha, op. cit. (ref. 7), 99.

21. G. Kellerman, "Towards the further interpretation of the purulli-festival", Slavica Hierosolymitana, v-vi (1981), 35-46.

22. For Eflatun Pinar, see Collins, op. cit. (ref. 12), 192. For Yazilikaya, see Seeher, op. cit. (ref. 4), 134-66.

23. For a general outline of Hittite temples, see Bryce, op. cit. (ref. 6), 153-6; and Burney, op. cit. (ref. 19), 276-8.

24. In particular, there are two interesting foundation texts, CTH413 and CTH481, including rituals for building a temple, Kellerman, op. cit. (ref. 14).

25. J. A. Belmonte, M. A. Molinero and N. Miranda, "Unveiling Seshat: New insights into the stretching of the cord ceremony", in In search of cosmic order, ed. by Belmonte and Shaltout (ref. 1), $193-210$.

26. See the introductory paragraph of this article. Also relevant is Haas, op. cit. (ref. 7), 619.

27. Bryce, op. cit. (ref. 6), 241; and Burney, op. cit. (ref. 19), 278.

28. The ruins of this small but important ancient village has been identified either with the sacred city of Arinna, the site of the Sun-goddess, or with the sacred city of Zippalanda, another important religious place of Hittite sacred geography. The discussion is open. See, for example, BerndtErsöz, op. cit. (ref. 5), 171.

29. Burney, op. cit. (ref. 19), 277. See also P. Neve, Hattusha information (Istanbul, 1985-87).

30. F. Cimok, Reliefs of Azatiwataya (Istanbul, 2008), presents an excellent edition of the reliefs of Karatepe monumental gates.

31. Taracha, op. cit. (ref. 7), 135.

32. Berndt-Ersöz, op. cit. (ref. 5), 171-2. For Mount Tudhaliya, see Kellerman, op. cit. (ref. 14), 104.

33. Bryce, op. cit. (ref. 6), 154.

34. M. E. Cohen, The cultic calendars of the ancient Near East (Maryland, 1993).

35. A. Taggar-Cohen, Hittite priesthood (Heidelberg, 2006), 117.

36. Taggar-Cohen, op. cit. (ref. 35), 181-2. The mention of the Pleiades in connection to the rituals celebrated during the purulli festival could also be relevant: Kellerman, op. cit. (ref. 21). For a 
complete summary of the different classes of Hittite priests and priestesses and their functions, see Taggar-Cohen, op. cit. (ref. 35), 435-44.

37. Taracha, op. cit. (ref. 7), 61 and 70-4; and Taggar-Cohen, op. cit. (ref. 35), 72.

38. Bryce, op. cit. (ref. 6), 188.

39. H. G. Güterbock, "An outline of the Hittite AN.TAH.SUM festival”, Journal of Near Eastern studies, xix (1960), 80-9; H. G. Güterbock, "Some aspects of Hittite festivals", in Actes de la xvii Rencontre Assyriologique Internationale, ed. by A. Finet (Brussels, 1970), 175-80; Ph. H. J. Houwink ten Cate, "Brief comments on the Hittite cult calendar: The outline of the AN.TAH. SUM festival”, Assyriological studies, xxiii (1986), 95-110.

40. Taggar-Cohen, op. cit. (ref. 35), 336; and Taracha, op. cit. (ref. 7), 139. See also Ph. H. J. Houwink ten Cate, "Brief comments on the Hittite cult calendar: The recension of the outline of the nuntarriyashas festival, especially days 8-12 and 15-22", in Documentum Asiae Minoris antiquae, ed. by E. Neu and C. Rüster (Weisbaden, 1988), 167-94.

41. Güterbock, op. cit. (ref. 39); and Taracha, op. cit. (ref. 7), 139. The exact location of the hešta-house is a matter of debate. Several authors located it within the acropolis of Hattusha in Büyyükkale (see Fig. 6), while others have suggested the open-air sanctuary of Yazilikaya. In this respect, the procession of gods and goddesses in Hall A of the sanctuary has frequently been related to the ceremonies of the New Year. See Krupp, op. cit. (ref. 3). As we will see in Section 1.4, this idea has been put aside today by the majority of the specialists. See Burney, op. cit. (ref. 19), 321. However, see ref. 61.

42. Houwink ten Cate, op. cit. (ref. 40); and Taggar-Cohen, op. cit. (ref. 35), 118.

43. I. Singer, The Hittite KI.LAM festival (Wiesbaden, 1983-84). See also Taggar-Cohen, op. cit. (ref. 35), 336; and Houwink ten Cate, op. cit. (ref. 40).

44. H. A. Hoffner Jr, Hittite myths (Atlanta, 1998), 11-12.

45. Hutter, op. cit. (ref. 7, 1997); and Kellerman, op. cit. (ref. 21).

46. Taggar-Cohen, op. cit. (ref. 35), 35.

47. Taggar-Cohen, op. cit. (ref. 35), 302; and Hutter, op. cit. (ref. 7, 1997).

48. Taracha, op. cit. (ref. 7), 29; and M. Popko, "Zum Tempel der Sonnengöttin von Arinna in Hattuša", Altorientalische Forschungen, xxx (2003), 11-17.

49. Taggar-Cohen, op. cit. (ref. 35), 121.

50. Taracha, op. cit. (ref. 7), 137. The words of Tudhaliya IV, "I shall never omit the festivals again nor shall I interchange the festivals and celebrate them at the right time", could be mentioned in this particular context: Houwink ten Cate, op. cit. (ref. 39).

51. Taracha, op. cit. (ref. 7), 70 and 136.

52. See, for example, M. Hoskin, Tombs, temples and their orientation: A new perspective on Mediterranean prehistory (Bognor Regis, 2001).

53. Bryce, op. cit. (ref. 6), 179. There exist, however, the exceptional high-rank proto-Hittite tombs of Alaca Hüyük, where the bronze astral representations of Fig. 2 were discovered. Interestingly, our own preliminary data on site show a main axis for all these tombs orientated within the solar range.

54. Bryce, op. cit. (ref. 6), 178-9.

55. Collins, op. cit. (ref. 12), 193-4; and Taracha, op. cit. (ref. 7), 162.

56. T. van de Hout, "Tombs and memorials: The (divine) Stone-house and hegur reconsidered", in Recent developments in Hittite archaeology and history, ed. by Aslihan Yener, Hoffner, and Dhesi (ref. 20), 73-92. See also Taracha, op. cit. (ref. 7), 134.

57. Taracha, op. cit. (ref. 7), 164-5.

58. S. Lumsden, "Gavurkalesi: Investigations at a Hittite sacred place", in Recent developments in Hittite archaeology and history, ed. by Aslihan Yener, Hoffner, and Dhesi (ref. 20), 111-26.

59. Taracha, op. cit. (ref. 7), 166. It has been suggested that the rocky-outcrops of Sarikale (much altered by later constructions) and Yenicekale, in Hattusha Upper City, could also be hekur-peak sanctuaries 
of other Hittite kings, see Seeher, op. cit. (ref. 4), 59.

60. Seeher, op. cit. (ref. 4), 98-106.

61. Burney, op. cit. (ref. 19), 321. Also relevant is Taracha, op. cit. (ref. 7), 92-5. The idea that Yazilikaya could indeed have been a multi-purpose sacred place has been nicely expressed by E. Krupp in his criticism of this paper: "I think I understand the current rejection by specialists of a connection between Yazilikaya and the New Year Festival, but I am suspicious this may be the product of typically fashionable reconsiderations that emphasize a particular component of the data at the expense of the other as one time and group of experts is replaced by another. The royal mortuary dimension of Yazilikaya and its underworld connotations neither contradict nor exclude the themes associated with renewal, regeneration, and New Year. The multiple components of Yazilikaya - architecturally, icongraphically, and physically — suggest caution. So much about Hittite ideology is obscure and complex; and it would be odd if Yazilikaya were simple. It isn't. Dismissal of any New Year connotation requires a powerful alternative explanation of the presence of a procession of the gods in the rather remarkable mobilization they display. The iconography has a focus that is indicated by the size of figures and their location. Those details must also be related to theme. The king, dead or alive, does not seem to play a role in the action on the main panel in Chamber A. How have the revisionists dealt with the text that has the gods assembling at the New Year?"

62. Taggar-Cohen, op. cit. (ref. 35), 148 and 271.

63. Taracha, op. cit. (ref. 7), 166.

64. Taracha, op. cit. (ref. 7), 83.

65. Taracha, op. cit. (ref. 7), 63-6.

66. For Sarissa temple maps, see A. Müller-Karpe, "Kuakli-Sarissa: A Hittite town in the Upper Land", in Recent developments in Hittite archaeology and history, ed. by Aslihan Yener, Hoffner, and Dhesi (ref. 20), 145-56. We would like to point out that direct measurements on Google Earth maps could also be useful if high resolution images were available (which is not always the case) for certain locations. However, Anatolian topography is so rough and complicated that, in most cases, the measurement of angular height becomes a crucial aspect for the correct interpretation of the data (see column 6 of Table 1). Indeed, in the case of Sarissa, we could not rely on the angular height information and its data should be considered as preliminary.

67. Seeher, op. cit. (ref. 4), 62-8, illustrates the more than probable religious significance of Yerkapi, the Sphinx Gate, in Hattusha.

68. Magnetic anomalies are not expected in central Anatolia, where most of the terrain is limestone. In any case, the temples were mostly measured along their main axis, from inside the sanctuary to the outermost gate and, on several occasions and always for monumental gates, also in the opposite direction, with checks for possible anomalies in the measurement.

69. Taggar-Cohen, op. cit. (ref. 35), 9.

70. Taracha, op. cit. (ref. 7), 65 and 135; and Taggar-Cohen, op. cit. (ref. 35), 115.

71. A. Süel, "Ortaköy-Šapinuwa", in Recent developments in Hittite archaeology and history, ed. by Aslihan Yener, Hoffner, and Dhesi (ref. 20), 145-56.

72. The mean is first computed and subtracted from the data. Then, the data are normalized with the standard deviation of the measurements. Any peak rising above the $3 \sigma$ level could be considered as having a $99 \%$ degree of confidence. Peaks between 0 and $3 \sigma$ would be real (our data have no noise) but should be treated with more caution and will not be considered in our analysis unless strictly necessary.

73. And for nearly all the Hittite period if the errors are considered. Curiously, most of these peaks were also found in the study of Egyptian temples, see Belmonte et al., op. cit. (ref. 1), Fig. 8.12.

74. Güterbock, op. cit. (ref. 11), 241. See also H. G. Güterbock, "An addition to the prayer of Mursili to the Sun-goddess and its implications", Anatolian studies, xxx (1980), 41-50.

75. Seeher, op. cit. (ref. 4), 157.

76. A burial-monument-solstitial connection has recently being established for another sophisticated 
ancient Anatolian mausoleum, the hierothesion of Antiochos I of Commagene, see J. A. Belmonte and A. C. González García; "Antiochos's hierothesion at Nemrud Dag re-visited: Adjusting the date in the light of new astronomical evidence", Journal for the history of astronomy, xli (2010), 469-81.

77. Taracha, op. cit. (ref. 7), 133-4.

78. Notably the purulli. See Burney, op. cit. (ref. 19), 53.

79. As suggested by Neve, op. cit. (ref. 29). See also Berndt-Ersöz, op. cit. (ref. 4), 149-50. However, our own data show that this is not exactly true, since the convergence of the three axes is not precise and occurs in a wide area close to the ruins of the Byzantine church (near number ' 8 ' in the plan of Fig. 6).

80. A similar reasoning could have been applied for the fall equinox and the classical date of Celtic Samhain in the case of the nuntarriyashas festival. On this occasion, however, according to our data (from inside, see Table 1), the orientation of the Lion and King Gates does not offer such similar values of the declination ( $-12 \frac{1}{4}$ versus $-14^{\circ}$, respectively). Anyway, a celebration of the nuntarriyashas festival in the 40 days elapsing from the fall equinox to the beginning of November is perfectly reasonable with the time "when the king returns from the battlefield" at the end of the summer campaigns. As a matter of fact, astronomy suggests that the monumental gates of Hattusha Upper City could have been involved in the ritual related to major Hittite festivals.

81. See Belmonte et al., op. cit. (ref. 1), Fig. 8.15. Also relevant is J. A. Belmonte, "Mediterranean archaeotopography and archaeoastronomy: Two examples of dolmenic necropolises in the Jordan Valley", Archaeoastronomy (JHA), no. 29 (1997), S37-43.

82. For the Egyptians, see J. Lull and J. A. Belmonte, "The constellations of ancient Egypt", in In search of cosmic order: Selected essays on Egyptian archaeoastronomy, ed. by Belmonte and Shaltout (ref. 1), 155-94. For Mesopotamia, see J. Rogers, "Origins of the ancient constellations, Parts I and II", Journal of the British Astronomical Association, cviii (1998), 9-28 and 79-89, and references therein. Finally, for the Achaeans: Homer, Iliad, Chant xviii.8-9, is the obvious reference.

83. In the case of Chamber 2, the achievement would be double since King Suppiluliuma II could have entered the realm of the Sun God of Heaven by crossing the backstone towards the noonculminating sun. A similar interpretation might then be given to the reliefs of the southern natural-rock wall of Gavurkalesi where a suspected image of an unknown king is addressing the Sun-goddess of Arinna (see Table 1).

84. The study of some myths, like the one of the fight between the serpent Illuyanka and the Storm-god of Hatti, within the frame of the purulli festival, could also be relevant in the context of the northern constellations, where the celestial serpent Draco might be connected with Illuyanka; see Bryce, op. cit. (ref. 6), 215-16.

85. Burney, op. cit. (ref. 19), 276-8.

86. D. S. Young, Gordion, aux fouilles et au musée (Ankara, 1975).

87. Berndt-Ersöz, op. cit. (ref. 4), 16-19.

88. Berndt-Ersöz, op. cit. (ref. 4), 127-8, 141 and 179, respectively.

89. Berndt-Ersöz's work, op. cit. (ref. 4), 314-23, offers a detailed selection of maps where Phrygian monuments can be easily looked for and identified.

90. The step monuments at Karahisar (see Fig. 8) may even show a double Hittite-Phrygian nature.

91. Berndt-Ersöz, op. cit. (ref. 4), 163.

92. Indeed, Berndt-Ersöz, op. cit. (ref. 4), and references therein, should be a perfect fieldwork assistant.

93. Due to the authors' ignorance of Hittite language(s), we are possibly losing some relevant information that a direct reading of the texts may perhaps offer. However, we expect that our new way of looking at the texts may encourage dedicated Hittitologists to carry on further with new and suggestive interpretations of specific paragraphs of ancient texts.

94. For Sarissa, see Müller-Karpe, op. cit. (ref. 66), and references therein. For the temples of Nesha, see Singer, op. cit. (ref. 9), 85 
95. Such as the monuments of the Neo-Hittite kingdoms. See S. Aro, "Art and architecture", in The Luwians, ed. by Melchert (ref. 6), 281-333. Also interesting is: http://www.hittitemonuments. $\mathrm{com} /$ 